\title{
Karakteristik Kualitatif dan Kuantitatif Induk Sapi Peranakan Onggole (PO) dan Persilangannya di Pacitan, J awa Timur
}

\section{The Qualitative and Quantitative Characteristics of Ongole Grade Cow and Its Crossbred in Pacitan, East J ava.}

\author{
Adisti Rastosari \\ Fakultas Peternakan Universitas Tulang Bawang Lampung. J I. Gajah Mada, Bandar \\ Lampung \\ adisti.rastosari@utb.ac.id
}

\begin{abstract}
This study aimed to determine the qualitative and quantitative characteristics of Ongole Grade Cow and its crossbreeding in Pacitan, East Java. This study used 105 cattles, which consist of 35 Ongole Grade Cattle, 35 LimPO and 35 SimPO. Ongole Grade's coat dominated by white color (100\%), coat of LimPO and SimPO dominated by light brown $(5.7 \%)$ and $(17.1 \%)$, brown $(68.6 \%)$ and $(57.1 \%)$, dark brown $(25.7 \%)$ both. The muzzle color's of Ongole Grade was (100\%) black, black (48.6\%) and brown (51.4\%) for LimPO, black (51.4\%) and brown (48.6\%) for SimPO. SimPO had a white color on its head. The tail and nail color's of Ongole Grade was (100\%) black, black (48.6\%) and brown $(51.4 \%)$ for LimPO, black (54.3\%) and brown (45.7\%) for SimPO. Body sizes consisted of the heart girth, withers height, body length, hip height and head index for Ongole Grade were $160.36 \pm 9.57$ $\mathrm{cm}$; $122.13 \pm 5.29 \mathrm{~cm} ; 113.81 \pm 8.52 \mathrm{~cm} ; 126.31 \pm 4.77 \mathrm{~cm}$; and $0.41 \pm 0.05$; for LimPO were $167.27 \pm 14.33 \mathrm{~cm} ; 128.59 \pm 8.02 \mathrm{~cm} ; 124.44 \pm 8.83 \mathrm{~cm} ; 131.43 \pm 8.29 \mathrm{~cm}$; and $0.47 \pm 0.06$; for SimPO were $164.67 \pm 8.59 \mathrm{~cm} ; 123.97 \pm 6.91 \mathrm{~cm} ; 126.44 \pm 9.64 \mathrm{~cm} ; 126.04 \pm 7.56 \mathrm{~cm}$; and $0.50 \pm 0.07$. From this results, it could be concluded that Ongole Grade, LimPO, and SimPO had different qualitative and quantitative characteristics which SimPO had a white color on its head. Heart girth, withers height, and hip height of LimPO were larger than SimPO and Ongole Grade whereas body length and head index of SimPO were larger than LimPO and Ongole Grade.
\end{abstract}

Key Words: Cow, LimPO, Ongole grade cattle, qualitative, quantitative, SimPO.

\section{PENDAHULUAN}

Sapi potong merupakan aset nasional di bidang pertanian sehingga keberadaannya perlu dilestarikan, dikembangkan, dan ditingkatkan populasi dan produktivitasnya dalam rangka kecukupan daging sapi pada tahun 2010 (Sumadi, 2009). Sapi Peranakan Ongole (PO) merupakan sapi potong lokal yang terbanyak di Indonesia, terutama di daerah Jawa Timur, Jawa Tengah, dan Daerah Istimewa Yogyakarta (Ngadiyono, 2007). Di Kabupaten Pacitan tahun 2007, hasil rekapitulasi jumlah kelahiran ternak sapi hasil inseminasi buatan pada tahun 2007 sebesar 13.076 ekor dan tahun 2008 sebesar 15.321 ekor, yang sebagian besar menggunakan semen pejantan dari Bos taurus yaitu Limousin dan Simmental (Dinas Tanaman Pangan dan Peternakan, 2009). Hal ini menunjukkan bahwa jumlah sapi LimPO dan SimPO di Kabupaten Pacitan besar. Namun demikian belum banyak penelitian tentang sapi persilangan di Kabupaten Pacitan, untuk itulah penelitian ini dilaksanakan. Penelitian ini bertujuan untuk mengetahui karakteristik kualitatif dan kuantitatif induksapi Peranakan Ongole dan persilangannya di Kabupaten Pacitan.

\section{MATERI DAN METODE}

Materi ternak yang digunakan sebanyak 105 ekor, antara lain 35 ekor sapi PO, 35 ekor sapi SimPO, dan 35 ekor sapi LimPO.Sapi yang diamati adalah sapi berjenis kelamin betina yang berumur dua hingga enam tahun. Alat yang digunakan dalam penelitian ini 
meliputi, pita ukur merek FHK dengan angka ketelitian $1 \mathrm{~cm}$, mistar ukur merek FHK dengan angka ketelitian $0,2 \mathrm{~cm}$.

Metode yang digunakan dalam penelitian ini adalah survei langsung ke peternak di Kabupaten Pacitan, Jawa Timur. Survei melibatkan peternak sapi sebagai responden dan dipilih lima kecamatan yang memiliki populasi sapi besar sebagai sampel yaitu Kecamatan Nawangan, Pacitan, Arjosari, Pringkuku, Punung.

Variabel yang diamati adalah profil peternak, umur ternak, karakteristik kualitatif dan kuantitatif. Karakteristik kualitatif yang diamati yaitu warna, profil muka, gelambir, telinga, tanduk, dan punuk. Karakteristik kuantitatif yang diamati yaitupanjang badan, lingkar dada, tinggi gumba, dan tinggi pinggul. Data dianalisis dengan deskriptif kuantitatif menggunakan program SPSS 16.

\section{Karakteristik kualitatif}

\section{HASIL DAN PEMBAHASAN}

Hasil penelitian untuk karakteristik eksterior sapi PO, sapi LimPO, dan sapi SimPO di Kabupaten Pacitan dapat dilihat pada Tabel 5. Pada Tabel 5, dapat dilihat perbedaan dan persamaan karakteristik eksterior antara sapi PO, sapi LimPO, dan sapi SimPO. Perbedaan di antara ketiga bangsa tersebut dapat dilihat pada warna tubuh, profil muka, telinga, dan punuk. Menurut Warwick et al. (1990), karakteristik eksterior ternak merupakan sifat kualitatif dari individu yang dikendalikan satu atau beberapa pasang gen dan sedikit atau tidak sama sekali dipengaruhi oleh faktor lingkungan.

Tabel 1. Karakteristik Eksterior Sapi PO, Sapi LimPO, dan Sapi SimPO di Kabupaten Pacitan

\begin{tabular}{|c|c|c|c|c|}
\hline No & Variabel & $\begin{array}{l}\text { Sapi PO } \\
(n=35)\end{array}$ & $\begin{array}{c}\text { Sapi LimPO } \\
(\mathrm{n}=35)\end{array}$ & $\begin{array}{l}\text { Sapi SimPO } \\
(n=35)\end{array}$ \\
\hline 1 & $\begin{array}{l}\text { Warna bulu } \\
\text { dominan } \\
\text { Putih } \\
\text { Coklat muda } \\
\text { Coklat } \\
\text { Coklat tua }\end{array}$ & $100 \%$ & $\begin{array}{c}5,7 \% \\
68,6 \% \\
25,7 \%\end{array}$ & $\begin{array}{l}17,1 \% \\
57,1 \% \\
25,7 \%\end{array}$ \\
\hline 2 & Warna lain & Tidak ada & Tidak ada & Putih di kepala \\
\hline 3 & Profil muka & Segitiga lurus & Datar & Datar \\
\hline 4 & $\begin{array}{l}\text { Moncong } \\
\text { Hitam } \\
\text { Coklat }\end{array}$ & $100 \%$ & $\begin{array}{l}48,6 \% \\
51,4 \% \\
\end{array}$ & $\begin{array}{l}51,4 \% \\
48,6 \% \\
\end{array}$ \\
\hline 5 & $\begin{array}{l}\text { Gelambir } \\
\text { Ada } \\
\text { Tidak ada }\end{array}$ & $100 \%$ & $\begin{array}{l}88,6 \% \\
11,4 \%\end{array}$ & $\begin{array}{c}91,4 \% \\
8,6 \%\end{array}$ \\
\hline 6 & Telinga & $\begin{array}{c}\text { Agak } \\
\text { menggantung }\end{array}$ & Tegak & Tegak \\
\hline 7 & $\begin{array}{l}\text { Tanduk } \\
\text { Ada } \\
\text { Tidak ada }\end{array}$ & $100 \%$ & $\begin{array}{l}88,6 \% \\
11,4 \%\end{array}$ & $\begin{array}{l}91,4 \% \\
8,6 \%\end{array}$ \\
\hline 8 & Punuk & Ada & Tidak ada & Tidak ada \\
\hline 9 & $\begin{array}{l}\text { Kipas ekor } \\
\text { Hitam } \\
\text { Coklat }\end{array}$ & $100 \%$ & $\begin{array}{l}48,6 \% \\
51,4 \%\end{array}$ & $\begin{array}{l}54,3 \% \\
45,7 \% \\
\end{array}$ \\
\hline 10 & $\begin{array}{l}\text { Tracak } \\
\text { Hitam } \\
\text { Coklat }\end{array}$ & $100 \%$ & $\begin{array}{l}48,6 \% \\
51,4 \%\end{array}$ & $\begin{array}{l}54,3 \% \\
45,7 \% \\
\end{array}$ \\
\hline
\end{tabular}


Sapi PO memiliki warna bulu dominan putih, berbeda dengan warna bulu dominan sapi LimPO dan sapi SimPO. sapi LimPO dan sapi SimPO memiliki warna bulu dominan coklat $68,6 \%$ dan $57,1 \%$; coklat tua $25,7 \%$;serta coklat muda $5,7 \%$ dan $17,1 \%$. Sapi SimPO memiliki warna putih di kepala, sesuai dengan yang dinyatakan oleh Hastuti (2008), sedangkan sapi LimPO tidak ada warna lain.

Profil muka sapi PO segitiga lurus sedangkan profil muka sapi Limpo dan sapi Simpo adalah datar. Telinga sapi PO agak menggantung, sesuai dengan yang dinyatakan oleh Abdurrahman (2006), sedangkan sapi LimPO dan sapi SimPO memiliki telinga yang tegak.Sapi PO memiliki punuk sedangkan sapi LimPO dan SimPO tidak memiliki punuk.

Moncong sapi PO berwarna hitam, berbeda dengan warna moncong sapi LimPO dan sapi SimPO. Moncong sapi LimPO berwarna hitam $48,6 \%$ dan coklat $51,4 \%$ sedangkan moncong sapi SimPO berwarna hitam $51,4 \%$ dan coklat $48,6 \%$.

Sapi PO memiliki gelambir sedangkan sapi LimPO dan sapi SimPO ada yang memiliki gelambir dan ada yang tidak memiliki gelambir. Sapi LimPO dan sapi SimPO yang memiliki gelambir sebanyak $88,6 \%$; $91,4 \%$ dan yang tidak memiliki gelambir $11,4 \%$ dan $8,6 \%$.

Sapi PO memiliki tanduk sedangkan sapi LimPO dan sapi SimPO ada yang memiliki tanduk dan ada yang tidak memiliki tanduk. Sapi LimPO dan sapi SimPO yang memiliki tanduk sebanyak 88,6\%; $91,4 \%$ dan yang tidak memiliki tanduk sebanyak $11,4 \%$ dan $8,6 \%$.

Kipas ekor dan tracak pada sapi PO berwarna hitam sedangkan kipas ekor dan tracak pada sapi LimPO dan sapi SimPO ada yang berwarna hitam dan ada yang berwarna coklat. Kipas ekor dan tracak sapi LimPO yang berwarna hitam sebanyak 48,6\% dan coklat $51,4 \%$. Kipas ekor dan tracak sapi SimPO yang berwarna hitam sebanyak $54,3 \%$ dan coklat 45,7\%. Menurut Abdurrahman (2006), sapi PO memiliki kipas ekor dan tracak yang berwarna hitam. Menurut Hastuti (2008), warna kipas ekor yang dimiliki oleh sapi LimPO dan sapi SimPO adalah hitam dan cokelat.

Karakteristik eksterior sapi PO antara lain warna bulu penutup tubuh dominan putih, profil muka segitiga lurus, telinga agak menggantung, memiliki gelambir dan tanduk, moncong, kipas ekor, dan tracak berwarna hitam.

Karakteristik eksterior sapi LimPO antara lain warna penutup bulu dominan coklat $68,6 \%$, coklat tua 25,7\%; dan coklat muda 5,7\%. Profil muka datar dan telinga tegak. Moncong sapi LimPO berwarna hitam $48,6 \%$ dan coklat $51,4 \%$. Sapi LimPO yang memiliki gelambir sebanyak $88,6 \%$ dan yang tidak memiliki gelambir $11,4 \%$. Sapi LimPO yang memiliki tanduk sebanyak $88,6 \%$ dan yang tidak memiliki tanduk sebanyak $11,4 \%$. Kipas ekor dan tracak sapi LimPO yang berwarna hitam sebanyak $48,6 \%$ dan coklat $51,4 \%$.

Karakteristik eksterior sapi SimPO memiliki warna bulu dominan coklat $57,1 \%$; coklat tua $25,7 \%$; serta coklat muda $17,1 \%$. Sapi SimPO memiliki warna putih di kepala. Profil muka datar dan telinga tegak. Moncong sapi SimPO berwarna hitam 51,4\% dan coklat $48,6 \%$. Sapi SimPO yang memiliki gelambir sebanyak $91,4 \%$ dan yang tidak memiliki gelambir $8,6 \%$. Sapi SimPO yang memiliki tanduk sebanyak $91,4 \%$ dan yang tidak memiliki tanduk sebanyak 8,6\%.Kipas ekor dan tracak sapi SimPO yang berwarna hitam sebanyak $54,3 \%$ dan coklat $45,7 \%$.

\section{Karakteristik kuantitatif}

Tabel 2. Rerata dan Standar Deviasi Ukuran Tubuh Sapi PO, Sapi LimPO, dan Sapi SimPO di Pacitan, Jawa Timur 


\begin{tabular}{clccc}
\hline \hline No & Variabel & Sapi PO $(\mathrm{n}=35)$ & Sapi LimPO $(\mathrm{n}=35)$ & $\begin{array}{c}\text { Sapi SimPO } \\
(\mathrm{n}=35)\end{array}$ \\
\hline 1 & Lingkar dada $(\mathrm{cm})$ & $160,36 \pm 9,57$ & $167,27 \pm 14,33$ & $164,67 \pm 8,59$ \\
\hline 2 & Tinggi gumba $(\mathrm{cm})$ & $122,13 \pm 5,29$ & $128,59 \pm 8,02$ & $123,97 \pm 6,91$ \\
\hline 3 & Panjang badan $(\mathrm{cm})$ & $113,81 \pm 8,52$ & $124,44 \pm 8,83$ & $126,44 \pm 9,64$ \\
\hline 4 & Tinggi pinggul $(\mathrm{cm})$ & $126,31 \pm 4,77$ & $131,43 \pm 8,29$ & $126,04 \pm 7,56$ \\
\hline 5 & Indeks kepala & $0,41 \pm 0,05$ & $0,47 \pm 0,06$ & $0,50 \pm 0,07$ \\
\hline
\end{tabular}

Hasil penelitian di lapangan terhadap ukuran tubuh sapi PO, sapi LimPO, dan sapi SimPO di Kabupaten Pacitan dapat dilihat pada Tabel 6. Tabel 6 berisi hasil analisis ukuranukuran tubuh sapi PO, sapi LimPO, dan sapi SimPO yang meliputi lingkar dada, tinggi gumba, pajang badan, tinggi pinggul, dan indeks kepala. Analisis yang digunakan adalah deskriptif kuantitatif. Menurut Warwick et al. (1990) dan Hardjosubroto (1994), ukuran tubuh merupakan sifat kuantitatif yang sebagian diatur oleh perbedaan genetik dan lingkungan.

Sapi LimPO memiliki rerata lingkar dada, tinggi gumba, dan tinggi pinggul lebih tinggi dibandingkan dengan sapi SimPO dan sapi $\mathrm{PO}$ sedangkan rerata panjang badan sapi SimPO lebih tinggi dibandingkan dengan sapi LimPO dan sapi PO.

Indeks kepala sapi SimPO lebih besar dari indeks kepala sapi Limpo dan indeks kepala sapi LimPO lebih besar dari sapi PO. Indeks kepala dipengaruhi oleh panjang kepala dan lebar kepala.

\section{KESIMPULAN}

Berdasarkan hasil pengamatan karakteristik kualitatif dan kuantitatif sapi PO dan persilangannya di Kabupaten Pacitan, diperoleh bahwa sapi PO, sapi LimPO dan sapi SimPO memiliki perbedaan karakteristik kualitatif. Karakteristik kuantitatif sapi hasil persilangan (sapi LimPO dan sapi SimPO) lebih besar daripada dengan sapi PO. Sapi LimPO memiliki rerata lingkar dada, tinggi gumba, dan tinggi pinggul lebih tinggi dibandingkan dengan sapi SimPO dan sapi PO sedangkan rerata panjang badan dan indeks kepala sapi SimPO lebih tinggi dibandingkan dengan sapi LimPO dan sapi PO.

\section{DAFTAR PUSTAKA}

Abdurrahman, M. A. 2006. Karakteristik eksterior sapi lokal di Kabupaten Pacitan Jawa Timur. Skripsi Sarjana Peternakan. Fakultas Peternakan. Universitas Gadjah Mada, Yogyakarta.

Dinas Tanaman Pangan dan Peternakan. 2009. Pacitan dalam Angka. Badan Pusat Statistik, Dinas Tanaman Pangan dan Peternakan Kabupaten Pacitan, Jawa Timur.

Hardjosubroto, W. 1994. Aplikasi Pemuliabiakan Ternak di Lapangan. PT Gramedia Widiasarana Indonesia, Jakarta.

Hastuti, I. T. 2008. Karakteristik Eksterior Sapi Betina Hasil Persilangan Antara Simmental dan Limousin dengan Sapi Peranakan Ongole di Kabupaten Bantul. Skripsi Sarjana Peternakan. Fakultas Peternakan. Universitas Gadjah Mada, Yogyakarta.

Ngadiyono, N. 2007. Beternak Sapi Potong. Citra Aji Parama, Yogyakarta.

Sumadi. 2009. Sebaran Populasi, Peningkatan Produktivitas dan Pelestarian Sapi Potong di Pulau Jawa. Pidato Pengukuhan Jabatan Guru Besar dalam Bidang Produksi Ternak pada Fakultas Peternakan Universitas Gadjah Mada, Yogyakarta.

Warwick, E. J., J. M. Astuti, dan W. Hardjosubroto. 1990. Pemuliaan Ternak. Gadjah Mada University Press, Yogyakarta. 


\title{
PENGARUH AROMATERAPI MINYAK ATSIRI J AHE TERHADAP KADAR TRIGLISERIDA DAN KOLESTEROL DARAH TIKUS YANG DIBERI PAKAN TINGGI LEMAK
}

\author{
Aji Agung Cahyaji ${ }^{1}$ \\ ${ }^{1}$ Fakultas Peternakan, Universitas Tulang Bawang Lampung, J I. Gajah Mada No. 34 , \\ Bandar Lampung
}

\begin{abstract}
The study aims to determine the effect of ginger (Zingiber officinale) essential oil via inhalation on blood triglyceride, total cholesterol, High Density Lipoprotein (HDL) cholesterol, and Low Density Lipoprotein (LDL) cholesterol level of rats that fed high fat diet. Eighteen albino rats (Rattus norvegicus) were devided into three treatments groups. The treatments were K1 (standard diet) as negative control, K2 (high fat diet) as positive control, and K3 (high fat diet + ginger essential oil inhalation). Blood samples were collected after 5 weeks of treatment period. The result showed the level of triglyceride, cholesterol, and HDL cholesterol at treatment K3 tend to be lower than treatment K2. LDL cholesterol level at treatment K3 show higher result than treatment K2. From the result of this study cocluded that inhalation of ginger essential oil can lowering triglyceride, total cholesterol, and LDL cholesterol level and raise HDL cholesterol level.
\end{abstract}

Keywords: triglyceride, cholesterol, HDL cholesterol, LDL cholesterol, ginger essential oil

\section{PENDAHULUAN}

Pola makan penduduksecara global telah berubah seiring dengan perkembangan zaman yang disebabkan majunya teknologi pengolahan makanan. Perubahan ini membawa dampak meningkatnya kecenderungan untuk mengonsumsi makanan berkadar lemak tinggi yang dapat menyebabkan timbulnya gangguan metabolisme lemak. Daryit (2003) menyatakan bahwa asupan makanan yang tinggi kadar lemak jenuh menyebabkan peningkatan kadar kolesterol serum darah.

Masalah metabolisme lemak yang sering terjadi pada masyarakat adalah hiperlipidemia. Hiperlipidemia adalah suatu gangguan metabolisme lipid yang ditandai dengan peningkatan kadar trigliserida dan kolesterol di dalam darah. Kondisi hiperlipidemia yang berkelanjutan memicu terbentuknya atherosklerosis yang menjadi dasar penyakit serebrovaskular dan kardiovaskular (Pon et al. 2008).

Kondisi hiperlipidemia dapat ditanggulangi dengan cara pengontrolan diet dan pemberian obat hipolipidemik. Namun demikian pemberian obat hipolipidemik mempunyai efikasi yang terbatas dan efek samping yang tidak diinginkan (Kreisberg et al. 2003).

Kini masyarakat mulai beralih menggunakan terapi herbal dalam pengobatan penyakit. Salah satu jenis terapi yang digunakan adalah aromaterapi. Aromaterapi adalah pengobatan menggunakan wewangian yang berasal dari ekstrak tanaman aromatik. Menurut Daniel (2000), aroma yang dihasilkan oleh tanaman berpotensi sebagai obat karena dapat diaplikasikan dengan cara menghirupnya melewati paru-paru kemudian efeknya akan ke otak yang akan mempengaruhi sistem saraf pusat di otak. Ekstrak tanaman yang digunakan dalam aromaterapi adalah minyak atsiri atau minyak esensial karena sifatnya yang mudah menguap sehingga mudah diinhalasi.

Minyak atsiri merupakan senyawa yang larut dalam lipid, sehingga komponenkomponen minyak atsiri mampu dengan cepat memasuki daerah yang kaya lemak di dalam tubuh (Buchbauer 1993). Assaat (2011) mengemukakan bahwa inhalasi senyawa etil-pmetoksisinamat dari minyak atsiri kencur pada tikus Sprague dawley mampu menurunkan kadar kolesterol dan trigliserida darah. 
Menurut Sharma et al. (1996), jenis tanaman aromatik lain yang mempunyai efek hipolipidemik adalah jahe (Zingiber oficinale). Sejak zaman dahulu, masyarakat Indonesia telah menggunakan jahe sebagai bumbu masak dan obat tradisional. Mahendra (2005) menyatakan bahwa jahe berkhasiat untuk mengobati batuk, kolera, dan sebagai afrodisiaka.

Melihat potensi terapeutik jahe, tidak menutup kemungkinan minyak atsirinya dikembangkan menjadi aromaterapi untuk menurunkan kadar kolesterol dan trigliserida darah.

\section{MATERI DAN METODE}

\section{Waktu dan Tempat}

Penelitian ini dilaksanakan mulai bulan Juni 2012 hingga Agustus 2012 di Pusat Studi Biofarmaka Lembaga Penelitian dan Pengabdian Masyarakat Institut Pertanian Bogor (PSBLPPM IPB).

\section{Bahan dan Alat}

Bahan yang digunakan pada penelitian ini adalah minyak atsiri jahe $1 \%$, serum darah tikus, pakan standar dan pakan tinggi kolesterol (produksi PT. Indofeed), kit Human ${ }^{\circledR}$ (produksi Gesellschaft) untuk mengukur kadar kolesterol total, kolesterol HDL, dan trigliserida; akuades, ketamin, xilazin, dan hewan coba berupa tikus putih. Minyak atsiri jahe yang digunakan diperoleh dari PSB-LPPM IPB. Kit yang digunakan untuk mengukur kadar kolesterol total dan trigliserida berisi reagen enzim dan kit yang digunakan untuk mengukur kadar kolesterol HDL berisi presipitan atau larutan pengendap.

Alat yang digunakan adalah kandang percobaan, inhalator, pipet mikro, microplate, microtube, spuit, alat sentrifugasi, tabung reaksi, lemari pendingin, spektrofotometer dan timbangan digital.

\section{Metode Penelitian}

Penelitian ini menggunakan 18 ekor tikus putih dengan bobot badan rata-rata sekitar 200 gram/ekor. Tikus tersebut dibagi dalam 3 kelompok, yaitu kelompok kontrol negatif (K1), kelompok kontrol positif (K2), kelompok perlakuan (K3). Masing-masing kelompok terdiri atas 6 ekor tikus. Proses adaptasi tikus dilakukan selama 2 minggu dengan memberikan pakan standar pada semua kelompok tikus sebanyak $20 \mathrm{~g} / \mathrm{ekor} / \mathrm{hari}$.

\section{Pemberian Pakan dan Inhalasi Minyak Atsiri}

Perlakuan pada hewan coba tikus berupa pemberian pakan standar, pakan tinggi lemak, dan inhalasi minyak atsiri dapat dilihat pada Tabel 2.

Tabel 2 Pemberian pakan dan inhalasi minyak atsiri*

\begin{tabular}{lccc}
$\begin{array}{l}\text { Kelompok } \\
\text { perlakuan }\end{array}$ & $\begin{array}{c}\text { Jumlah pakan } \\
\text { standar (g/ekor/hari) }\end{array}$ & $\begin{array}{c}\text { Jumlah pakan tinggi } \\
\text { lemak } \\
\text { (g/ekor/hari) }\end{array}$ & $\begin{array}{c}\text { Inhalasi minyak } \\
\text { atsiri }\end{array}$ \\
\hline K1 & 20 & - & - \\
\hline K2 & - & 20 & - \\
\hline K3 & - & 20 & $\sqrt{ }$ \\
\hline
\end{tabular}

Keterangan

- : tidak dilakukan perlakuan

$\checkmark$ : dilakukan perlakuan

* : dilakukan selama 5 minggu

\section{Pengambilan Sampel Darah}

Pengambilan sampel darah dilakukan setelah 5 minggu perlakuan. Tikus dianestesi menggunakan xilazin ${ }^{\circledR}$ dan ketamin ${ }^{\circledR}$ dengan dosis masing-masing $10 \mathrm{mg} / \mathrm{kg}$ dan $100 \mathrm{mg} / \mathrm{kg}$. Tikus kemudian difiksasi ke papan bedah pada keempat alat geraknya. Rongga dada dibedah dan darah dalam jantung diambil sebanyak $3 \mathrm{ml}$ menggunakan spuit $5 \mathrm{ml}$. Darah 
dimasukkan ke tabung darah. Darah yang telah diambil disentrifugasi pada kecepatan 4000 rpm selama 10 menit untuk mendapatkan serumnya.

\section{Pengukuran Kadar Kolesterol Total}

Pengukuran kadar kolesterol total menggunakan uji kalorimetrik enzimatik metode CHOD-PAP (cholesterol oxidase p-aminophenazone). Serum darah $(5$ I) dan standar $(5$ I) masing-masing dicampur reagen $(500$ l). Kemudian serum, standar, dan blanko diinkubasi selama 20 menit pada suhu $25^{\circ} \mathrm{C}$ dan dibaca absorbansinya pada panjang gelombang 500 $\mathrm{nm}$ menggunakan spektrofotometer.

\section{Pengukuran Kadar Trigliserida}

Pengukuran kadar trigliserida menggunakan uji kalorimetrik enzimatik metode GPOPAP (glycerol phospate oxidase p-aminophenazone). Serum darah $(5$ I) dan standar (5 I) masing-masing dicampur reagen $(500$ l). Serum, standar dan blanko diinkubasi selama 20 menit pada suhu $25^{\circ} \mathrm{C}$ dan dibaca absorbansinya pada panjang gelombang $500 \mathrm{~nm}$ menggunakan spektrofotometer.

\section{Pengukuran Kadar Kolesterol HDL}

Pengukuran kadar kolesterol HDL dilakukan dengan mengendapkan kilomikron, kolesterol VLDL, dan kolesterol LDL terlebih dahulu dengan cara menambahkan reagen presipitan. Serum darah $(100$ l) ditambah presipitan $(250$ l) dan diinkubasi selama 10 menit pada suhu ruang. Setelah itu, campuran disentrifugasi pada kecepatan $4000 \mathrm{rpm}$ selama 10 menit. Supernatan yang jernih dipisahkan dan diuji kadar kolesterol HDL menggunakan metode CHOD-PAP seperti pada pengukuran kolesterol total.

\section{Pegukuran Kadar Kolesterol LDL}

Penentuan kadar kolesterol LDL dilakukan dengan kalkulasi kolesterol total, kolesterol HDL, dan kadar trigliserida menggunakan rumus F riedwald:

Kolesterol $\mathrm{LDL}=$ kolesterol total - kolesterol $\mathrm{HDL}-\left(\frac{\text { trigliserida }}{5}\right)$

\section{HASIL DAN PEMBAHASAN}

Hasil pengujian kadar lipid serum menunjukkan bahwa kadar kolesterol total, kadar trigliserida, kadar kolesterol LDL berbeda signifikan dari setiap kelompok perlakuan, sedangkan kadar kolesterol HDL tidak menunjukkan perbedaan signifikan. Kadar lipid serum darah tikus setelah 5 minggu pada setiap kelompok perlakuan dapat dilihat pada Tabel 4.

Tabel 4. Kadar lipid serum darah tikus setelah 5 minggu perlakuan

\begin{tabular}{|c|c|c|c|c|c|c|}
\hline $\begin{array}{l}\text { Kelompok } \\
\text { slakuan }\end{array}$ & $\begin{array}{l}\text { Kadar } \\
\text { Kolesterol total } \\
\text { (mg/dL) }\end{array}$ & $\begin{array}{l}\text { Kadar } \\
\text { Trigliserida } \\
\text { (mg/dL) }\end{array}$ & $\begin{array}{l}\text { Kadar } \\
\text { kolesterol } \\
(\mathrm{mg} / \mathrm{dL})\end{array}$ & LDL & $\begin{array}{l}\begin{array}{l}\text { Kadar } \\
\text { kolesterol } \\
\text { (mg/dL) }\end{array} \\
\end{array}$ & HDL \\
\hline K1 & $70.13 \pm 11.62^{a}$ & $46.56 \pm 7.62^{a}$ & \multicolumn{2}{|c|}{$28.84 \pm 10.50^{a}$} & \multicolumn{2}{|c|}{$31.97 \pm 12.00^{\mathrm{a}}$} \\
\hline K2 & $104.76 \pm 9.28^{b}$ & $74.00 \pm 13.37^{b}$ & \multicolumn{2}{|c|}{$61.68 \pm 8.92^{\mathrm{b}}$} & \multicolumn{2}{|c|}{$28.28 \pm 11.74^{a}$} \\
\hline K3 & $89.92 \pm 9.24^{c}$ & $43.65 \pm 10.12^{c}$ & \multicolumn{2}{|c|}{$45.05 \pm 11.65^{c}$} & \multicolumn{2}{|c|}{$36.18 \pm 12.14^{a}$} \\
\hline
\end{tabular}

\section{Kadar Kolesterol Total}

Kadar kolesterol total merupakan gabungan dari semua kolesterol yang ada di dalam darah. Piliang dan Djojosoebagyo (2006) menyatakan bahwa kolesterol yang terdapat di dalam darah berasal dari makanan (kolesterol eksogen) dan dari sintesis di dalam tubuh (kolesterol endogen), meskipun di dalam tubuh tidak dapat dibedakan antara kolesterol eksogen dan endogen. 
Kadar kolesterol total pada kelompok tikus yang diberikan pakan standar masih berada dalam kadar normal yaitu $70.13 \pm 11.62 \mathrm{mg} / \mathrm{dL}$. Menurut Smith dan Mangkoewidjojo (1988), kadar normal kolesterol total pada tikus adalah 40-130 mg/dL. Kadar kolesterol total pada tikus yang diberikan pakan tinggi lemak (104.76 \pm 9.28) lebih tinggi dibandingkan dengan tikus yang hanya diberikan pakan standar, meskipun masih dalam kadar normal. Peningkatan kadar kolesterol total tersebut sebesar $49,44 \%$ menunjukkan pebedaan yang signifikan. Kolesterol dalam darah dapat meningkat apabila jumlah kolesterol yang berasal dari bahan pangan lebih besar daripada yang dihasilkan oleh tubuh (Russel 2007). Cullen (2000) menyatakan bahwa diet tinggi lemak dapat meningkatkan kadar kolesterol total, kolesterol LDL, dan trigliserida yang menyebabkan meningkatnya risiko kejadian penyakit jantung koroner.

Kadar kolesterol total tikus yang diberikan pakan tinggi lemak dan juga diberikan inhalasi minyak atsiri kadarnya lebih rendah (89.92 \pm 9.24$)$ dibandingkan dengan tikus yang hanya diberikan pakan tinggi lemak (104.76 \pm 9.28$)$. Perbedaan kadar kolesterol total yang terjadi pada kedua perlakuan tersebut sebesar $16.52 \%$.

Penurunan kadar kolesterol total terjadi karena komponen minyak atsiri jahe mempengaruhi sintesa asam empedu kolesterol di hati. Tanabe et al. (1993) melalui penelitiannya menyatakan bahwa beberapa senyawa yang diisolasi dari jahe seperti (E)-8 beta, 17-epoxyllabed-12-ene-15, 16-dial mempengaruhi biosintesis kolesterol di hati pada mencit hiperkolesterolemik. Asam empedu dibuat dari kolesterol, rangsangan untuk eksresi asam empedu berarti semakin banyak kolesterol yang dimanfaatkan untuk dibuat asam empedu, sehingga kolesterol total menurun.

\section{Kadar Trigliserida}

Kadar trigliserida pada kelompok tikus yang diberikan pakan standar masih berada dalam kadar normal yaitu $46.56 \pm 7.62 \mathrm{mg} / \mathrm{dL}$. Menurut Smith dan Mangkoewidjojo (1988) serta Suckow et al. (2006), kadar normal trigliserida pada tikus adalah 25-145 mg/dL. Kadar trigliserida pada tikus yang diberikan pakan tinggi lemak (74.00 \pm 13.37$)$ lebih tinggi dibandingkan dengan tikus yang hanya diberikan pakan standar. Perbedaan kadar trigliserida tersebut sebesar $58.93 \%$ dan menunjukkan perbedaan yang signifikan. Peningkatan kadar trigliserida dapat terjadi pada pemberian pakan tinggi lemak. Menurut Damron (2003), kadar trigliserida dalam darah dipengaruhi oleh kadar lemak yang dicerna dari makanan atau banyaknya lemak yang masuk dari luar tubuh. Selain itu Katan et al. (1997) dan Connor (1997) menyatakan bahwa kandungan karbohidrat yang tinggi dalam pakan dapat meningkatkan kadar trigliserida dalam darah.

Kadar trigliserida tikus yang diberikan pakan tinggi lemak dan juga diberikan inhalasi minyak atsiri kadarnya lebih rendah (43.65 \pm 10.12$)$ dibandingkan dengan tikus yang hanya diberikan pakan tinggi lemak (74.00 \pm 13.37). Perbedaan kadar trigliserida yang terjadi pada kedua perlakuan tersebut sebesar $69.53 \%$ dan menunjukkan perbedaan yang signifikan.

Penurunan kadar trigliserida terjadi karena adanya pengaruh minyak atsiri jahe terhadap sistem saraf. Menurut Matsuoka dan Mitsunaga (2011), aromaterapi meningkatkan kerja saraf simpatik pada reseptor olfaktori hingga mengeluarkan noradrelanin pada hipotalamus. Kemudian trigliserida akan diubah menjadi asam lemak bebas oleh beta reseptor akibat gertakan dari noradrenalin hingga melepaskan panas.

Penurunan kadar trigliserida sejalan dengan penurunan kadar kolesterol total serum darah setelah pemberian inhalasi minyak atsiri jahe. Hal ini dapat terjadi karena kadar trigliserida dan kolesterol saling berhubungan dimana trigliserida merupakan salah satu pembentuk kolesterol. Piliang dan Djojosoebagio (2006) menyatakan bahwa selain dapat dipakai sebagai energi, trigliserida dapat dihidrolisis dan disintesis kembali untuk membentuk fosfolipid dan kolesterol.

\section{Kadar Kolesterol LDL}

Kadar kolesterol LDL pada kelompok tikus yang diberikan pakan standar yaitu 28.84 $\pm 10.50 \mathrm{mg} / \mathrm{dL}$. Kadar kolesterol LDL pada tikus yang diberikan pakan tinggi lemak (61.68 \pm 8.92) lebih tinggi dibandingkan dengan tikus yang hanya diberikan pakan standar. Peningkatan kadar kolesterol LDL tersebut sebesar $113.86 \%$ menunjukkan perbedaan yang signifikan antara kedua perlakuan. Kadar kolesterol LDL darah bergantung pada konsumsi 
lemak dari pakan. Grundy (1991) menyatakan bahwa pakan tinggi lemak dapat menghambat dan menekan pembentukan reseptor LDL, sehingga kadar LDL meningkat dalam darah. Peningkatan kadar LDL memiliki arti penting bagi kesehatan yaitu sebagai penyebab terjadinya atherosklerosis. Kadar kolesterol LDL yang tinggi dalam peredaran darah dapat menumpuk atau menempel pada dinding pembuluh darah arteri baik yang menuju ke otak maupun ke jantung. Akibat yang ditimbulkan dari hal tersebut adalah terbentuknya plak yang tebal dan mengeras serta dapat mempersempit arteri dan membuatnya tidak fleksibel.

Kadar kolesterol LDL tikus yang diberikan pakan tinggi lemak dan juga diberikan inhalasi minyak atsiri kadarnya lebih rendah (45.05 \pm 11.65$)$ dibandingkan dengan tikus yang hanya diberikan pakan tinggi lemak $(61.68 \pm 8.92)$. Perbedaan kadar kolesterol LDL antara kedua perlakuan tersebut sebesar $36.91 \%$ dan menunjukkan perbedaan signifikan.

Penurunan kadar kolesterol LDL setelah pemberian inhalasi minyak atsiri karena penurunan kadar kolesterol total. Hubungan LDL dan total kolesterol akan bersifat searah karena $65 \%$ kolesterol berada dalam bentuk LDL. Penurunan kolesterol terjadi karena terhambatnya atau terganggunya proses penyerapan kolesterol di usus dan eksresi asam empedu yang lebih besar. Oleh karena asam empedu terbuat dari kolesterol, maka rangsangan untuk eksresi asam empedu berarti meningkatkan laju metabolisme kolesterol sehingga menurunkan total kolesterol dan kadar LDL. Turunnya kadar kolesterol LDL ini dapat menurunkan risiko terjadinya atherosklerosis.

Fuhrman et al. (2000) melalui penelitiannya menyatakan bahwa ekstrak etanol jahe dapat menurunkan kadar kolesterol darah dan menghambat oksidasi LDL pada kejadian atherosklerosis. Komponen ekstrak minyak esensial jahe yang berperan dalam menghambat oksidasi LDL adalah gingerol, shogaol dan zingerone.

Kemungkinan lain yang terjadi seperti yang dinyatakan oleh Neess et al. (1996) bahwa penurunan kadar LDL terjadi karena penurunan sintesis LDL itu sendiri dan penginduksian reseptor hepatik. Akibatnya banyak LDL yang ditangkap reseptor hepatik sehingga konsentrasinya dalam darah menurun.

\section{Kadar Kolesterol HDL}

Kadar kolesterol HDL pada kelompok tikus yang diberikan pakan standar yaitu 31.97 $\pm 12.00 \mathrm{mg} / \mathrm{dL}$. Kadar kolesterol HDL pada tikus yang diberikan pakan tinggi lemak (28.28 \pm 11.74) lebih rendah dibandingkan dengan tikus yang hanya diberikan pakan standar, namun tidak berbeda signifikan. Perbedaan kadar kolesterol HDL antara kedua perlakuan tersebut hanya sebesar $13.04 \%$.

Kadar kolesterol HDL tikus yang diberikan pakan tinggi lemak dan juga diberikan inhalasi minyak atsiri kadarnya lebih tinggi $(36.18 \pm 12.14)$ dibandingkan dengan tikus yang hanya diberikan pakan tinggi lemak, namun perbedaan ini tidak terjadi secara signifikan. Perbedaan kadar kolesterol HDL antara kedua perlakuan tersebut sebesar 27,93\%.

Peningkatan kadar HDL disebabkan oleh turunnya kadar LDL dalam darah karena meningkatkannya reseptor LDL di hati (Neess et al. 1996). Turunnya konsentrasi LDL akan berdampak peningkatan konsentrasi HDL, hal ini terjadi karena penurunan LDL akan menyebabkan organ hati kekurangan kolesterol untuk membuat asam empedu. Kondisi demikian akan merangsang sintesis kolesterol HDL dalam hati dan menyebabkan kadar HDL darah meningkat.

Peningkatan kadar HDL yang terjadi sangat bermanfaat dalam menurunkan risiko atherosklerosis. HDL yaitu lipoprotein yang mengangkut kolesterol dari jaringan periferal ke hati. HDL mengangkut kolesterol bebas dari pembuluh darah dan jaringan lain menuju hati, kemudian hati mengekresikannya melalui empedu (Dalimartha 2003).Selain itumenurut Moeliandari dan Wijaya (2002), HDL memiliki efek antioksidan yang dapat mencegah oksidasi LDL, sehingga kolesterolnya tidak menempel di dinding pembuluh darah arteri.

\section{KESIMPULAN}

Minyak atsiri jahe yang diaplikasikan perinhalasi selama 5 minggu dapat menurunkan kadar kolesterol total, trigliserida, dan kolesterol LDL serta dapat meningkatkan kadar kolesterol HDL darah tikus yang diberi pakan tinggi lemak. 


\section{DAFTAR PUSTAKA}

Assaat, L.D. 2011. Fraksionasi senyawa aktif minyak atsiri kencur (Kaemferia galanga L.) sebagai pelangsing [disertasi]. Bogor: Fakultas Matematika dan IImu Pengetahuan Alam, Institut Pertanian Bogor.

Barnett, S.A. dan M.M. Spencer. 2001. Responses of wild rats to offensive smells and tastes. Brit. J. Anim. Behav. 1:32-37.

Buchbauer, G. 1993. Biological effects of fragrances and essential oils. Journal Perfumer and flavorist. 18:19-24.

Connor, W.E. 1997. Should a low-fat, high-carbohydrate diet be recommended for everyone?. N. Engl. J. Med. 337:562-563.

Cullen, P. 2000. Evidence that triglycerides are an independent coronary heart disease risk factor. Am J Cardiol. 186(9):943-9.

Damron, W.S. 2003. Introduction to Animal Science:Biological, Industry, Perspective. New Jersey: Prentice Hall.

Daniel, M. 2000. Medical Plants Chemistry and Properties. New York: Science publisher.

Dalimartha, S. 2003. 36 Resep Tumbuhan Obat untuk Menurunkan Kolesterol. Jakarta: Penebar Swadaya.

Daryit, C.S. 2003. Coconut oil: atherogenic or not? (what therefore causes atherosclerosis?). Philip J Cardiol 31:77-104.

Fuhrman, B., M. Roseblate, T. Hayek, R. Coleman, Aviram M. 2000. Ginger extract consumption reduces plasma cholesterol, inhibits LDL oxidation and attenuates development of atherosclerosis in atherosclerotic, apolipoprotein E-Deficient mice. J. Nutr. 130: 1124-1131.

Grundy, S.M. 1991. Multifactorial etiology of hypercholesterolemia: implication for prevention coronary heart disease, ateriosclerosis and trombosis. Am.J.Cardiol. 11: 1619-1635.

Katan, M.B., M.S. Grundy, W.C. Willet. 1997. Beyond low-fat diets. N. Engl. J. Med. 337: 563-567.

Kreisberg, Robert A, Oberman A. 2003. Medical management of hyperlipidemia/ dyslipidemia. The Journal of Clinical Endocrinology and Metabolism 88(6):2445-61.

Mahendra, B. 2005. 13 Jenis Tanaman Obat Ampuh. Jakarta: Penerbit Swadaya.

Matsuoka, R., Mitsunaga T. 2011. Effects of olfactory stimulation with scent of cypress (Callitris glaucophylla) essential oil on brown adipose tissue sympathetic nerve activity of rat. Proceeding of The second symposium on Temulawak, Bogor.

Moeliandari, F., A. Wijaya. 2002. Metabolism and Anti-Atherosclerotic Mechanisms of HDL, A New Perspective. Jakarta: Prodia.

Neess GC, Zhao Z, Lopez D. 1996. Inhibitor of cholesterol biosynthesis increase hepatic low density lipoprotein degradation. Arch. Biochem. Biophys. 325:242-248.

Piliang WG, Djojosoebagyio S. 2006. Fisioligi Nutrisi Volume II. Bogor: IPB Press.

Pon V, Babu A, Liu D. 2008. Green tea cathecin and cardiovascular health: an update. Curr. Med. Chem. 15(18): 1840-1850.

Russel M. 2007. What you might not know about cholesterol [terhubung berkala]. http://cholesterol-guide-to.com [26 September 2012].

Sharma I, Gusain D, Dixit VP. 1996. Hypolipidemic and antiatherosclerotic effects of Zingiber officinale in cholesterol-fed rabbits. Phto. Res. 10:517-518.

Smith, J.B., S. Mangkoewidjojo. 1988. Pemeliharaan, Pembiakan, dan Penggunaan Hewan Percobaan di Daerah Tropis. Jakarta: UI Press.

Suckow, M.A., S.H. Weisbroth, C.L. Franklin. 2006. The Laboratory Rat. San Diego: Elsevier Academic Press.

Tanabe, M., Y.D. Chen, K. Saito dan Y. Kano. 1993. Cholesterol biosynthesis inhibitory component from Zingiber officinale Roscoe. Chem. Pharm. Bull. 41: 710-713. 


\title{
Pengaruh Pemberian Bungkil Kelapa Sawit Segar (BKS) dan Fermentasi (BKSF) Terhadap Kualitas Fisik Telur Itik
}

\section{The Effect Of Utilization Fresh and Fermented Palm Kernel Cake in Diets on Physical Quality of Egg Duck}

\author{
Arif Pranata ${ }^{1}$ \\ ${ }^{1}$ Fakultas Peternakan, Universitas Tulang Bawang Lampung, J I. Gajah Mada, Bandar \\ Lampung \\ 13arifpranatab@gmail.com
}

\begin{abstract}
This research was conducted to utilize fresh and fermented palm kernel cake in the ducks diets on egg physical quality. One hundred and five laying ducks were randomly devided in to five diets treatments in three replications with seven laying ducks each the dietary treatments were $\mathrm{K}=$ control, was diet without palm kernel cake, BKS 10 and BKS 30 diets with addition $10 \%$ and $30 \%$ fresh palm kernel cake, BKSF 10 and BKSF 30 diets with addition $10 \%$ and $30 \%$ fermented palm kernel cake. The data collected were egg mass, shell thickness, Haugh Unit and yolk colour and will be analyzed by a one way classification of variance analysis (CRD), followed by testing the significant mean by Duncan's New Multiple Range Test (DMRT). The results showed the egg mass, shell thickness, and HU had not significant different and egg mass were $(64,74,65,71,67,22,65,39,63,52 \mathrm{~g})$, shell thickness were $(0,47,0,49,0,44,0,48,0,45 \mathrm{~mm})$, Haught Unit were $(86,81,87,44,90,94$, $88,15,88,08 \%)$. Yolk colour had significant different between the treatment $(9.31,9,72,9,81$, $10,69,10,74)$. It be concluded that the utilization $30 \%$ of fresh and fermented palm kernel cake in feed duck had not increase egg mass, shell tickness, and haugh unit, except on yolk colour.
\end{abstract}

Key words :Fermentation, Egg Quality, Laying Duck, Palm kernel cake

\section{PENDAHULUAN}

Beberapa faktor dapat mempengaruhi kualitas telur itik, terkadang tidak hanya satu faktor tetapi merupakan kombinasi dari beberapa faktor. Faktor tersebut antara lain adalah : umur itik, pakan dan lingkungan tempat pemeliharaan itik serta kombinasi dari faktor-faktor tersebut. Salah satu upaya untuk memperbaiki kualitas itik ini adalah dengan cara pemberian pakan yang berkualitas. Persoalan yang sering ditemui oleh peternak itik yang memelihara itik dengan cara intensif adalah penyediaan bahan pakan yang berkualitas untuk menghasilkan telur itik dengan kualitas yang baik. Saat ini bahan pakan untuk unggas belum dapat dicukupi dari dalam negeri saja tetapi masih harus mendatangkan dari luar negeri.

Harga pakan merupakan faktor penentu yang paling utama dalam perhitungan biaya produksi industri perunggasan yang besarnya dapat mencapai $60 \%$ dari total biaya produksi. Naiknya harga bahan pakan unggas tidak serta merta diikuti dengan kenaikan harga produk yang di produksi dan sebagai akibatnya para peternak banyak yang mengalami kerugian. Penggunaan bahan pakan utama untuk ransum unggas seperti jagung dan kedelai juga masih menjadi persoalan karena pengadaanya masih saling berbenturan dengan kebutuhan manusia.

Dewasa ini telur itik yang beredar di pasaran yang berasal dari pemeliharaan secara intensif, sebagian besar kuning telurnya berwarna pucat. Hal itu tampaknya disebabkan oleh pemberian ransum yang defisiensi akan pigmen karotenoid. Telah diketahui bahwa pakan mempengaruhi warna dari kuning telur, yaitu bahan pakan yang mengandung pigmen 
karotenoid terutama pigmen beta karoten dan xantofil (Prasetyo dan Ketaren, 2005). Saat ini pakan itik yang banyak diberikan masih belum mencukupi kebutuhan ternak itik untuk berproduksi dengan baik. Kebanyakan itik yang dipelihara dimasyarakat hanya diberi pakan ala kadarnya saja seperti campuran dari bekatul dengan sisa-sisa limbah rumah tangga. Sehingga produksi dan kualitas dari telur itik masih sangat rendah. Untuk memperbaiki hal tersebut, dibutuhkan adanya bahan pakan alternatif yang murah dan berkualitas. Limbah atau byproduct dari hasil pertanian dan perkebunan memiliki potensi untuk dikembangkan sebagai bahan pakan alternatif salah satunya adalah bungkil kelapa sawit.

Pemberian bahan pakan alternatif dari hasil samping industri pangan dan pertanian adalah cara yang tepat mengingat industri pertanian di Indonesia sedang mengalami pertumbuahan yang pesat terutama industri pengolahan kelapa sawit yang juga menghasilkan bungkil kelapa sawit sebagai hasil sampingan industri.

Kelapa sawit merupakan salah satu tanaman perkebunan di Indonesia. Tanaman kelapa sawit termasuk tumbuhan pohon yang tingginya mencapai $24 \mathrm{~m}$ (Sunarko, 2007). Bungkil Kelapa Sawit (BKS) merupakan hasil samping proses ekstraksi daging buah kelapa sawit yang diperoleh dari ekstraksi minyak dari bagian mesocarp (Hair-Bejo dan Alimon, 1995). Bahan ini dapat diperoleh dengan proses kimia atau dengan cara mekanik (Mirwandhono dan Siregar, 2004). Data dari FAO mengindikasikan Indonesia adalah produsen terbesar kelapa sawit terbesesar kedua di dunia setelah Malaysia, dan mengalami peningkatan yang spektakuler yaitu 100\% per tahun dalam kurun waktu dua dekade terakhir (Sundu, 2004). Setiap ton buah kelapa sawit dapat menghasilkan $35 \mathrm{~kg}$ bungkil kelapa sawit (Mathius, 2008). Dengan demikian bungkil kelapa sawit memiliki potensi yang besar untuk dijadikan sumber bahan pakan ternak.

Ezieshi dan Olomu (2007) melaporkan bahwa kandungan beberapa jenis bungkil kelapa sawit yang berasal dari perlakuan ekstraksi yang berbeda memiliki kandungan nutrisi yang berbeda pula. Bungkil kelapa sawit Okomu merupakan bungkil kelapa sawit hasil ekstraksi dengan menggunakan cara mekanik, bungkil kelapa sawit Fresco merupakan bungkil dari proses ekstraksi secara kimia yaitu menggunakan pelarut lemak sedangkan bungkil kelapa sawit Envoy merupakan bungkil dari proses ekstraksi dengan metode kombinasi antara ekstraksi mekanik dan menggunakan pelarut lemak. Kandungan nutrisi ketiga bungkil kelapa sawit dengan metode ekstraksi yang berbeda tersebut dapat dilihat pada Tabel 1.

Tabel.1 Kandungan nutrisi bungkil kelapa sawit dengan metode ekstraksi yang berbeda

\begin{tabular}{lrrr}
\hline \hline \multirow{2}{*}{ Parameter } & \multicolumn{3}{c}{ Tipe B ungkil Kelapa Sawit } \\
\cline { 2 - 4 } & Okomu & Fresco & Envoy \\
\hline Kadar Air $(\%)$ & 8,26 & 8,25 & 8,05 \\
PK (\%) & 14,50 & 16,60 & 19,24 \\
SK (\%) & 10,00 & 12,29 & 17,96 \\
LK (\%) & 9,48 & 7,59 & 1,30 \\
Abu (\%) & 4,34 & 3,88 & 3,40 \\
ETN (\%) & 53,42 & 51,39 & 50,05 \\
AME (Kcal/Kg) & 2654 & 2423 & 1817 \\
\hline
\end{tabular}

Sumber : Ezieshi dan Olomu ( 2007)

Adanya kandungan SK yang tinggi pada bungkil kelapa sawit memerlukan sedikit sentuhan teknologi yang diharapkan mampu meningkatkan nilai nutrisi yang dapat dimanfaatkan bagi ternak. Kecernaan dari pakan ditentukan terutama oleh komposisi kimia (khusunya komponen serat), mungkin dapat ditingkatkan melalui penambahan enzim (McDonald et al., 2002). Salah satu teknologi sederhana yang dapat dilakukan yaitu dengan menerapkan teknologi fermentasi untuk meningkatkan nilai nutrisi. 
Fermentasi merupakan suatu proses yang terjadi melalui kerja mikroorganisme atau enzim untuk mengubah bahan-bahan organik kompleks seperti protein, karbohidrat dan lemak menjadi molekul yang lebih sederhana (Winarno dan Fardiaz, 1980). Adanya fermentasi bungkil kelapa sawit mwnggunakan isolat mikrobia dari rumen ternak sapi adalah untuk menurunkan serat kasar bungkil kelapa sawit yang jumlahnya masih relatif tinggi sehingga bungkil kelapa sawit hasil fermentasi dapat digunakan sebagai pakan unggas. Di dalam rumen terdapat bermacam-macam mikrobia salah satunya adalah bakteri selulolitik (Kamra, 2005). Bakteri selulolitik dalam rumen dapat menghasilkan enzim selulase yang selanjutnya akan mencerna selulosa yang akan dihidrolisis menjadi glukosa (Jouany, 1991).

Tujuan dari penelitian ini adalah untuk mengetahui pengaruh pemberian bungkil kelapa sawit segar dan fermentasi terhadap kualitas fisik telur itik. Diharapkan dengan pemberian bungkil kelapa sawit segar dan fermentasi dapat meningkatkan kualitas fisik telur itik.

\section{MATERI DAN METODE}

\section{Tempat dan Waktu Penelitian}

Pemeliharaan itik selama penelitian berlangsung dilakukan di kandang penelitian Laboratorium IImu Ternak Unggas Fakultas Peternakan UGM Yogyakarta. Penelitian dimulai dari bulan maret 2009 sampai dengan bulan agustus 2009. Analisis kualitas fisik telur sampel dilakukan di Laboratorium IImu Ternak Unggas Fakultas Peternakan UGM.

\section{Materi}

\section{Itik Percobaan}

Ternak yang digunakan dalam penelitian ini adalah 147 ekor itik petelur lokal yang berasal dari daerah Bantul Yogyakarta dengan umur 22 mingu.

\section{Pakan dan Air Minum}

Bahan pakan yang digunakan dalam penelitian ini adalah jagung, bekatul, konsentrat itik merk Comfeed, bungkil kelapa sawit, premix vitamin merk Top Mix, minyak kelapa sawit dan pasir sebagai pelengkap. Pakan dan air minum diberikan secara ad libitum. Ransum yang diberikan pada itik adalah ransum basal yang disusun berdasarkan kandungan bahan pakan pada Tabel 2a dengan formulasi dapat dilihat pada Tabel $2 b$.

\section{Kandang dan peralatan}

Kandang yang digunakan dalam penelitian adalah kandang litter dengan ukuran $1 \mathrm{x}$ $1.5 \mathrm{~m}$ dengan perlengkapannya seperti tempat minum, dan tempat pakan. Perlengkapan lain yang digunakan sebagai penunjang penelitian diantaranya timbangan, ayakan, timbangan digital kapasitas $2 \mathrm{~kg}$ dengan kepekaan $2 \mathrm{~g}$ yang digunakan untuk mengukur berat telur itik dan berat pakan. Peralatan yang digunakan untuk menganalisis kualitas telur adalah jangka sorong, deeph micrometer, timbangan analitik dengan kepekaan $0.01 \mathrm{~g}$, deeph micrometer digunakan untuk mengukur tinggi yolk dan albumen, shell thickness micrometer untuk mengukur ketebalan kerabang serta yolk colour fan untuk mengukur warna kuning telur 
Tabel 2a. Kandungan nutrien bahan pakan yang digunakan dalam penelitian

\begin{tabular}{lrrrrr}
\hline \hline Bahan pakan & PK(\%) & $\mathbf{C a}(\%)$ & $\mathbf{P}(\%)$ & SK(\%) & ME(kcal/Kg) \\
\hline Konsentrat & 37,5 & 13,5 & 1,6 & 6 & 1900 \\
\hline Jagung & 8,5 & 0,02 & 0,28 & 2,2 & 3350 \\
\hline Dedak & 12 & 3 & 0,8 & 5 & 2700 \\
\hline BKS & 16,1 & 0,29 & 0,79 & 15,7 & 1480 \\
\hline BKSF & 16.8 & 0,32 & 0.81 & 14,3 & 1485 \\
\hline Minyak & 0 & 0 & 0 & 0 & 8600 \\
\hline Premix & 0 & 0 & 0 & 0 & 0 \\
\hline Pasir & 0 & 0 & 0 & 0 & 0 \\
\hline
\end{tabular}

Sumber : hasil analisis laboratorium Biokimia Nutrisi Fakultas Peternakan UGM

Keterangan : BKS = bungkil kelapa sawit segar, BKSF : bungkil kelapa sawit fermentasi

Tabel 2b. Susunan bahan pakan yang digunakan dalam penelitian

\begin{tabular}{|c|c|c|c|c|c|}
\hline Bahan pakan (\%) & Kontrol & $\begin{array}{l}\text { BKS } \\
10 \%\end{array}$ & $\begin{array}{l}\text { BKS } \\
30 \%\end{array}$ & $\begin{array}{r}\text { BKSF } \\
10 \%\end{array}$ & $\begin{array}{r}\text { BKSF } \\
30 \%\end{array}$ \\
\hline Jagung & 40,00 & 30,00 & 31,00 & 30,00 & 31,00 \\
\hline Bekatul & 39,00 & 37,00 & 12,00 & 37,00 & 18,00 \\
\hline BKS & 0 & 10,00 & 30,00 & 0 & 0 \\
\hline BKF & 0 & 0 & 0 & 10,00 & 30,00 \\
\hline Konsentrat & 21,00 & 20,00 & 20,00 & 20,00 & 20,00 \\
\hline Minyak & 0 & 2,00 & 6,00 & 2,00 & 6,00 \\
\hline Mineral mix & 0 & 1,00 & 1,00 & 1,00 & 1,00 \\
\hline Jumlah & 100,00 & 100,00 & 100,00 & 100,00 & 100,00 \\
\hline \multicolumn{6}{|c|}{ Kandungan nutrient } \\
\hline PK (\%) & 15,95 & 16,12 & 16,41 & 16,19 & 16,32 \\
\hline $\mathrm{Ca}(\%)$ & 4,01 & 3,85 & 3,15 & 3,68 & 3,32 \\
\hline P (\%) & 0,76 & 0,78 & 0,74 & 0,77 & 0,74 \\
\hline SK $(\%)$ & 4,09 & 5,76 & 7,19 & 5,28 & 6,70 \\
\hline $\mathrm{ME}(\mathrm{kcal} / \mathrm{kg})$ & $2.792,00$ & $2.704,00$ & $2.702,50$ & 2702,00 & $2.704,50$ \\
\hline
\end{tabular}

Sumber : hasil analisis laboratorium Biokimia Nutrisi Fakultas Peternakan UGM

Keterangan : BKS = bungkil kelapa sawit segar, BKSF = bungkil kelapa sawit fermentasi

\section{METODE}

\section{Penempatan ternak}

Seratus lima ekor itik dibagi secara acak kedalam lima kelompok perlakuan yaitu Kontrol, BKS $10 \%$, BKSF $10 \%$, BKS $30 \%$ dan BKSF $30 \%$ yang setiap kelompok masing-masing memiliki tiga ulangan dan tiap ulangannya terdapat tujuh ekor itik. 


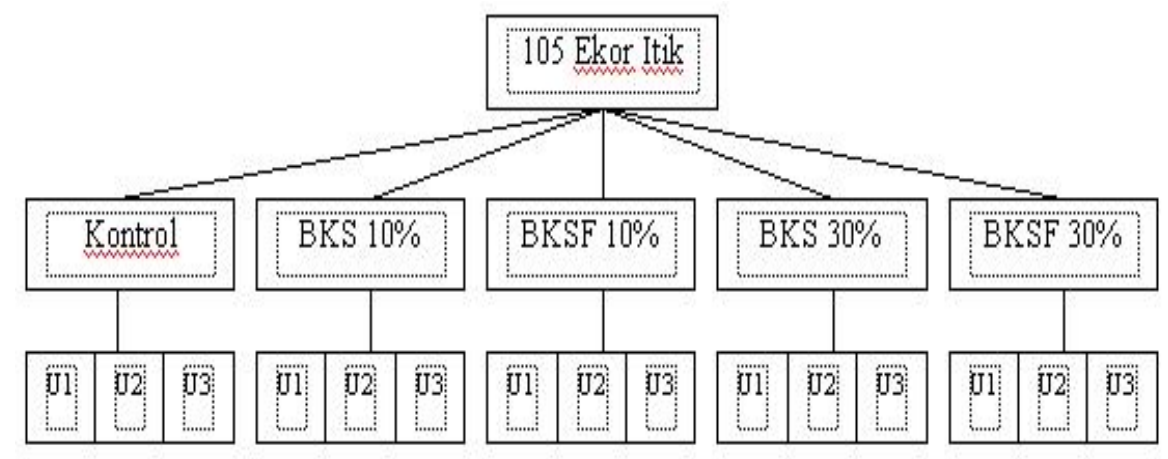

Gambar 1. Skema Perlakuan saat penelitian

Kontrol merupakan perlakuan tanpa pemberian bungkil kelapa sawit pada ransum, BKS $10 \%$ merupakan perlakuan pemberian bungkil kelapa sawit sebanyak $10 \%$ dari total ransum, BKSF $10 \%$ merupakan perlakuan dengan pemberian bungkil kelapa sawit fermentasi sebanyak 10\% dari total ransum, BKS 30\% merupakan perlakuan dengan penambahan bungkil kelapa sawit segar sebanyak 30\% dari total ransum, dan BKSF $30 \%$ merupakan perlakuan dengan penambahan bungkil kelapa sawit fermentasi sebanyak $30 \%$ dari total ransum.

\section{Fermentasi Bungkil Kelapa Sawit}

Fermentasi dilakukan dengan cara mencampur $5 \mathrm{~kg}$ bungkil kelapa sawit dengan 2.25 liter aquadest, isolat bakteri seluloitik dan xilanolitik dengan perbandingan 1:1. Setelah di homogenisasi, BKS di peram selama 21 hari dalam keadaan an aerob.

\section{Pengambilan Sampel}

Pengambilan sampel telur dilakukan setiap siklus peneluran 28 hari selama 3 hari berturut-turut pada hari ke-26, 27, dan 28 pada 5 perlakuan pakan dan 3 replikasi. Pada setiap replikasi di ambil 2 butir telur secara acak selama tiga hari berturut-turut kemudian dianalisis.

\section{Variabel Yang Diamati}

Pengujian kualitas telur yang dilakukan meliputi : pengukuran berat telur, nilai HU, Ketebalan Kerabang dan warna Yolk.

\section{Berat Telur}

Berat Telur dilakukan dengan menimbang telur itik dengan menggunakan timbangan analitik dengan kepekaan $0.01 \mathrm{~g}$ dalam satuan $\mathrm{g}$.

\section{Nilai HU (Haugh Unit)}

Nilai HU merupakan logaritma dari tinggi albumen kental dikalikan 100 dan dibagi dengan berat telur. Nilai HU di hitung dengan menggunakan persamaan logaritma sebagai berikut :

$$
\begin{aligned}
& \mathrm{HU}=100 \log \left(\mathrm{H}+7.57-1.7 \mathrm{~W}^{0.37}\right) \\
& \mathrm{H}=\text { Tinggi albumen Kental }(\mathrm{mm}) \\
& \mathrm{W}=\text { Berat Telur }(\mathrm{g})
\end{aligned}
$$




\section{Ketebalan Kerabang}

Untuk mengukur ketebalan kerabang, dibuat pecahan kerabang dengan ukuran yang kecil, kemudian diukur ketebalannya menggunakan shel thickness micrometer sebanyak tiga kali pada bagian ujung tumpul, ujung lancip dan pada bagian tengah kemudian hasil pengukuran di ambil rata-ratanya.

\section{Warna Yolk}

Warna Yolk ditentukan dengan mencocokkan warna dari kuning telur dengan yolk colour fan yang mempunyai skor 1-15. Skala satu berwarna kuning muda dan skala 15 berwarna kuning kemerahan.

\section{Analisis Data}

Data yang diperoleh dalam penelitian ini di analisis dengan metode rancangan acak lengkap pola searah dan jika perlakuan menunjukkan perbedaan yang signifikan dilanjutkan dengan uji Duncan multiple range test (Astuti, 2007). Analisis ini menggunakan program SPSS 15 for windows.

\section{HASIL DAN PEMBAHASAN}

Tabel 3. Pengaruh penggunaan BKS dan BKSF terhadap berat telur (g/butir)

\begin{tabular}{lrrrrr}
\hline \hline Ulangan & \multicolumn{5}{c}{ Perlakuan } \\
& Kontrol & BKSF 10\% & BKS10\% & BKSF 30\% & B KS 30\% \\
\cline { 2 - 6 } & 61,53 & 64,13 & 64,53 & 60,47 & 59,17 \\
2 & 65,71 & 64,67 & 67,17 & 66,37 & 65,47 \\
3 & 67,00 & 68,33 & 69,97 & 69,33 & 65,93 \\
\hline Rerata & & & & 65,39 & 63,52 \\
\hline
\end{tabular}

Tabel 4. Pengaruh penggunaan BKS dan BKSF terhadap tebal kerabang telur $(\mathrm{mm})$

\begin{tabular}{lrrrrr}
\hline \hline Ulangan & \multicolumn{5}{c}{ Perlakuan } \\
& Kontrol & B KSF 10\% & BKS10\% & BKSF 30\% & B KS 30\% \\
\cline { 2 - 6 } & 0,49 & 0,48 & 0,47 & 0,48 & 0,47 \\
2 & 0,48 & 0,62 & 0,47 & 0,56 & 0,48 \\
3 & 0,45 & 0,39 & 0,40 & 0,41 & 0,42 \\
\hline Rerata & 0,47 & 0,49 & 0,44 & 0,48 & 0,45 \\
\hline & & & & &
\end{tabular}


Tabel 5. . Pengaruh penggunaan BKS dan BKSF terhadap nilai Haugh Unit

\begin{tabular}{lrrrrr}
\hline \hline Ulangan & \multicolumn{5}{c}{ Perlakuan } \\
\cline { 2 - 6 } & Kontrol & BKSF 10\% & BKS10\% & BKSF 30\% & B KS 30\% \\
\hline 1 & 90,82 & 91,06 & 91,01 & 91,71 & 94,24 \\
2 & 86,94 & 89,20 & 91,39 & 86,11 & 85,05 \\
3 & 82,67 & 82,08 & 90,43 & 86,63 & 84,95 \\
\hline Rerata & 86,81 & 87,44 & 90,94 & 88,15 & 88,08 \\
\hline NS : Non Signifikan & & & &
\end{tabular}

Tabel 6. . Pengaruh penggunaan BKS dan BKSF terhadap warna kuning telur

\begin{tabular}{lrrrrr}
\hline \hline Ulangan & \multicolumn{5}{c}{ Perlakuan } \\
\cline { 2 - 6 } & Kontrol & BKSF 10\% & BKS10\% & BKSF 30\% & B KS 30\% \\
\hline 1 & 9,11 & 10,17 & 10,50 & 11,06 & 10,44 \\
2 & 9,33 & 9,00 & 9,25 & 10,78 & 11,06 \\
3 & 9,50 & 10,00 & 9,67 & 10,22 & 10,72 \\
\hline RerataSig & $9,31^{\mathrm{a}}$ & $9,72^{\mathrm{a}}$ & $9,81^{\mathrm{a}}$ & $10,69^{\mathrm{b}}$ & $10,74^{\mathrm{b}}$ \\
\hline sig : Signifikan $\mathrm{P}<0,05$ & & & &
\end{tabular}

\section{Berat Telur}

Hasil penelitian menunjukkan bahwa pemberian bungkil kelapa sawit segar maupun fermentasi hingga $30 \%$ berpengaruh tidak nyata terhadap berat telur. Kualitas telur eksterior yang paling utama adalah ukuran berat telur. Ukuran dan komposisi telur dipengaruhi oleh status pakan, genetik, program pencahayaan, (North, 1984) umur dan berat badan ayam (Etches, 1996).

Faktor terpenting dalam pakan yang mempengaruhi berat telur adalah protein dan asam amino, karena kurang lebih dari $50 \%$ dari bahan kering telur adalah protein. Hunton (1995) melaporkan bahwa berat telur sangat dipengaruhi oleh kandungan protein dalam pakan dan Appleby et al. (1992) menyebutkan bahwa berat telur akan semakin meningkat bila terjadi peningkatan protein dalam pakan.

Berat telur pada hasil penelitian menunjukkan perbedaan yang tidak nyata antara setiap perlakuannya, hal ini di karenakan dengan penambahan BKS dan BKSF hingga 30\% dari total ransum tidak mempengaruhi jumlah kandungan protein ransum, sehingga jumlah protein ransum yang diberikan pada setiap perlakuannya adalah tidak berbeda. Yuwanta (1995) melaporkan bahwa perubahan kandungan protein pakan dari 17 menjadi $15 \%$ atau dari 17 menjadi $13 \%$ tidak berpengaruh terhadap berat telur. Pada bungkil kelapa sawit yang difermentasi (BKSF) tidak terjadi kenaikan jumlah protein bahan pakan hal ini dikarenakan pada proses fermentasi isolat yang digunakan adalah isolat bakteri fibriolitik 
yang fungsinya mengubah serat kasar menjadi komponen yang lebih sederhana sehingga dapat dicerna oleh itik. Fermentasi yang dilakukan terhadap bungkil kelapa sawit tidak meningkatkan protein dalam pakan sehingga berat telur dari perlakuan BKS dan BKSF hasilnya berbeda tidak nyata.

\section{Tebal Kerabang}

Hasil Penelitian menunjukkan bahwa pemberian bungkil kelapa sawit segar maupun fermentasi dari level pemberian 10 sampai $30 \%$ berpengaruh tidak nyata terhadap ketebalan kerabang telur itik.

Salah satu faktor yang mempengaruhi tebal tipisnya kerabang adalah jumlah kalsium. Sumber kalsium dalam pembentukan kerabang berasal dari pakan yang terdapat dalam saluran pencernaan dan cadangan dalam tulang-tulang medular yang mudah dimobilisasi (Amrullah, 2003). Tidak ada perbedaan pada tebal kerabang di antara perlakuan BKS dan BKSF, hal ini di karenakan proses fermentasi bungkil kelapa sawit tidak menambah kandungan $\mathrm{Ca}$ dari BKSF sehingga tidak ada pengaruh pemberian BKSF terhadap ketebalan kerabang telur itik.

Kualitas kerabang dapat dipengaruhi oleh beberapa faktor, yaitu konsumsi pakan, konsumsi phospour, serta pengaturan cahaya (Yuwanta, 1992). Raharjo (1998) melaporkan bahwa terdapat pengaruh umur itik terhadap tebal kerabang. Ketebalan kerabang tidak hanya tergantung pada umur itik, namun lebih berhubungan dengan ketersediaan $\mathrm{Ca}$ dan $\mathrm{P}$ pakan dan kemampuan ternak dalam mengabsorbsi $\mathrm{Ca}$ dan $\mathrm{P}$ pakan yang cukup untuk digunakan dalam pembentukan kerabang.

\section{Haugh Unit}

Dari hasil analisis variansi terhadap nilai haugh unit telur itik yang diberi BKSF dan BKS, dapat diketahui bahwa pemberian BKSF dan BKS sampai $30 \%$ berpengaruh tidak nyata terhadap nilai HU telur itik. Nilai HU pada penelitian ini tidak berbeda dikarenakan berat telur selama penelitian setelah dianalisis variansi juga tidak berbeda nyata. Dewi (2002) melaporkan bahwa terdapat hubungan antara berat telur dan Haugh Unit. Berat telur yang cenderung meningkat akan menyebabkan nilai HU yang semakin besar. Nilai HU telur dipengaruhi oleh berat telur dan kualitas putih telur, sedangkan kualitas putih telur dipengaruhi oleh kandungan protein pakan. Proses permentasi BKS pada penelitian tidak menaikkan kandungan protein, sehingga jumlah protein pakan disetiap perlakuannya tidak berbeda dan penambahan BKSF pada ransum tidak mempengaruhi nilai HU telur itik.

Variabel yang mempengaruhi nilai Haugh Unit adalah putih telur dan berat telur (Scott et al, 1982). Sulit untuk menunjukkan pengaruh pakan terhadap nilai Haugh Unit, semakin tinggi nilai Haugh Unit menunjukkan kualitas albumen semakin baik (Stadlleman dan Cotterill, 1995).

\section{Warna Kuning Telur}

Hasil analisis variansi menunjukkan bahwa penambahan BKSF dan BKS sampai 30 $\%$ dari total ransum berpengaruh terhadap warna kuning telur itik $(P<0,05)$. Setelah di uji dengan uji beda rata-rata terdapat perbedaan yang nyata antara warna kuning telur pada perlakuan BKS dan BKSF pada level $30 \%$ hal ini dikarenakan ada perbedaan kadar xanthofil didalam BKS dan BKSF. Perbedaan xanthofil yang dikandung BKS dan BKSF di gambarkan oleh kandungan xanthofil kuning telur pada penelitian yaitu : pada perlakuan kontrol, BKS $10 \%$ dan BKSF $10 \%$ berturut-turut mengandung xanthofil sebesar $0,29,0,29$ dan $0,27 \mathrm{mg}$ per $100 \mathrm{~g}$ kuning telur. Sedangkan pada perlakuan BKS dan BKSF 30\% memiliki kandungan xanthofil telur sebanyak 0.34 dan $0.33 \mathrm{mg}$ per $100 \mathrm{~g}$ kuning telur.

Setelah dilakukan uji beda rata-rata, dapat diketahui pemberian BKS dan BKSF sampai $30 \%$ dari total ransum memiliki efek yang nyata terhadap warna kuning telur itik jika dibandingkan dengan perlakuan kontrol, BKS dan BKSF 10\% Hal ini dikarenakan warna kuning telur dipengaruhi oleh apa yang diserap dari makanannya, warna kuning telur 
dihasilkan oleh kelompok bahan yang disebut hidroxy carotenoids dari bagian beberapa jenis tanaman seperti daun, batang, buah dan akar (umbi), pada penelitian ini digunakan bungkil dari buah kelapa sawit, sedangkan yang paling berpotensi sebagai penyumbang warna alami adalah xanthophil, yang terdiri dari lutein dan zeaxanthin yang terdapat pada pakan (Marsumiyanto, 1989 cit supriadi, 2002). Tidak terdapat perbadaan yang nyata antara perlakuan kontrol, BKS dan BKSF 30\%, hal ini dikarenakan dengan penambahan BKS dan BKSF sebanyak $10 \%$ belum dapat menaikkan kandungan xanthofil telur untuk menaikkan nilai warna kuning telur. Pada penambahan BKS dan BKSF sampai level $30 \%$ dapat meningkatkan nilai warna kuning telur itik jika dibandingkan dengan perlakuan kontrol, BKS dan BKSF 10\%, hal ini di karenakan pada perlakuan BKS dan BKSF sebanyak 30\% meningkatkan kadar xanthofil telur sehingga dapat menaikkan nilai warna kuning telur.

Variasi warna kuning telur disebabkan oleh banyak faktor, diantaranya adalah : perbedaan strain, kemampuan genetik dalam mengabsorbsi dan deposisi xanthophyl, stress, lemak, oksidasi xanthophyl dan produksi telur (North dan Bell, 1990)

\section{KESIMPULAN}

Dari hasil Penelitian ini, dapat ditarik kesimpulan bahwa pemberian bungkil kelapa sawit segar dan fermentasi tidak meningkatkan kualitas fisik (berat, tebal kerabang dan $\mathrm{HU}$ ) kecuali warna kuning telur itik dan pemberian bungkil kelapa sawit fermentasi (BKSF) dan bungkil kelapa sawit segar sebanyak $30 \%$ dapat menaikkan nilai warna kuning telur itik.

\section{DAFTAR PUSTAKA}

Amrullah, I. K. 2003. Nutrisi ayam petelur. Penerbit : lembaga satu gunung budi. Bogor

Appleby, M.C., Hughes and H.A. Elson.1992. Poultry Production System. CAB International. Redwood Press Itd, Melksham.

Astuti, M. 2007. Pengantar IImu Statistik Untuk Peternakan dan Kesehatan Hewan. Cetakan Pertama Binasti Publisher. Bogor.

Dewi, Trias R. L. 2002. Kualitas Telur Itik Turi yang Mendapat Feed Aditif Dalam Ransum Dengan Tingkat Serat Kasar Yang Berbeda. Skripsi S1. Fakultas Peternakan. Universitas Gadjah Mada. Yogyakarta.

Etches, R.J. 1996. Reproduction in Poultry CAB international. Departement of Animal Science. University of Guelph, Ontario, Canada.

Ezieshi, E.V., and Olomu, J. M. 2007. Nutritional Evaluation of Palm Kernel Meal type: 1. Proximate composition and metabolizable energy values. Departement Of Animal Science. University Of Bevin. Nigeria

Hair-Bejo M and A.R Alimon. 1995. The protective role of zinc in palm kernel cake (PKC) toxicity in sheep. Faculty of Veterinary Medicine and Animal Science, Universiti Pertanian Malaysia, 43400 UPM Serdang. Mal. J. Nutr. 1:75-82.

Hunton. P. 1995. Poultry Production. The Ontaria Egg Producers Marketing Board Mississagua, Ontario, Canada.

Jouary, J.P. 1991. Rumen Microbial Metabolism and ruminant digestion. Institute National De La Recherche Agronomique. Paris.

Kamra, D. M. 2005. Rumen Microbial ecosystem. Current Science. Vol 89 (1) : 124-135 
Mathius, I.W. 2008. Pengembangan sapi potong berbasis industry kelapa sawit. Pengembangan inovasi pertanian 1(2): 206-224. http://www.pustaka-deptan .go.id/publikasi/ip013083.pdf. diakses tanggal 13 april 2010.

McDonald, P., R.a Edwards, J.F.D. Greenhalg, and C.A. Morgan. 2002. Animal Nutrition $6^{\text {th }}$ Edition. Pearson, Prentice Hall.

Mirwandhono, E dan Z. Siregar. 2004. Pemanfaatan Hidrolisat Tepung Kepala Udang dan Limbah Kelapa Sawit yang di Fermentasi dengan aspergilus niger, Rhizophus Oligosporus, dan Trichoderma Viridae dalam ransum ayam pedaging. Fakultas Pertanian, Universitas Sumatera Utara.

North, M. D. dan D. D. Bell. 1990. Commercial Chicken Production Manual. 4th ed. Avi Pub. Co. Inc. Westport, Connecticut.

North, M.D. 1984. Commercial Chicken Production Manual. 3nd ed. Avi Pub. Co. Inc. Westport, Connecticut.

Prasetyo, L.H dan Ketaren P.P. 2005. Interaksi antara bangsa itik dan kualitas ransum pada produksi dan kualitas telur itik local. Seminar Nasional Tekhnologi Peternakan dan Veteriner. Balai Litbang Ternak. Bogor.

Raharjo, I. L. Pengaruh umur terhadap kualitas telur pada itik yang dipelihara secara intensif. Skripsi S1. Fakultas Peternakan. Universitas Gadjah Mada. Yogyakarta.

Scott, M. L., M. C. Nesheim and R. J. Young. 1982. Nutrition Of The Chicken. $3^{\text {th }}$ Editions. L. Scott and Associates. Ithaca, Newyork.

Stadelman, W. J., and O. J Cotterill. 1995. Egg Science and Technology. Fourth Edition. Avi Publishing.Co., Inc. Westport, Conecticut.

Sundu, B. 2004. Bungkil Kelapa Sawit Untuk Pakan Broiler. HTTP//www.poultry Indonesia.com//. Diakses tanggal 13 april 2010.

Sunarko. 2007. Petunjuk Praktis Budidaya dan Pengolahan Kelapa Sawit. Agromedia Pustaka, Jakarta.

Supriyadi, 2005. Kualitas fisik telur burung puyuh yang mendapat ransum mengandung minyak sawit dan minyak ikan lemuru serta penambahan vitamin E. Skripsi S1. Fakultas Peternakan Universitas Gadjah Mada. Yogyakarta.

Yuawanta, T. 2002. Telur dan produksi telur. Fakultas Peternakan. Universitas Gadjah Mada. Yogyakarta.

Yuwanta, T. 1995. Mengapa Telur Mudah Pecah. Gallusia edisi 09 Thn.X.

Yuwanta, T. 1992. Pengaturan cahaya dan pakan alternative pada ayam broiler breeder : pengaruhnya terhadap pola konsumsi pakan dan ritme peneluran, fertilitas dan kualitas telur. Jurnal ilmiah . laporan penelitian ternak grati $2: 89-92$.

Winarno, F.G., dan S Fardiaz. 1980. Biofermetasi dan Biosintesa Protein. Angkasa. Bandung. 


\title{
PENGARUH PERSENTASE PEMBERIAN RANSUM PADA SIANG DAN MALAM HARI TERHADAP BOBOT HIDUP, BOBOT KARKAS, DAN BOBOT GIBLET AYAM PETELUR J ANTAN TIPE MEDIUM DI KANDANG PANGGUNG
}

\section{EFFECT OF DAY AND NIGHT FEED PERCENTAGE ON LIVE, CARCASS, AND GIBLET WEIGHT OF LAYERS MALE ON PANGGUNG CAGE}

\author{
Cintia Agustin Patria ${ }^{1}$ \\ Program Studi Produksi Ternak, Politeknik Negeri Lampung, J I.Soekarno Hatta No 10, \\ Bandar Lampung
}

\begin{abstract}
This study aimed at evaluating the effect of feeding time system and percentage on body weight, carcass and giblets of layers males. Two hundred and eighty eight 3 weeks old male layers were rearing and randomly distributed on three groups (R1, R2, and R3). R1 were feeding $30 \%$ during the day and $70 \%$ at night, R2 were feeding $50 \%$ during the day and $50 \%$ at night, R3 were feeding $70 \%$ during the day and $30 \%$ at night. Body weight, carcass weight and giblet weight were not significanly affected $(P>0.05)$ by all of feeding time system and percentage.
\end{abstract}

Keyword : Body weight, carcass, giblet feeding Time.

\section{PENDAHULUAN}

Ayam jantan tipe medium merupakan salah satu jenis ternak yang dapat memenuhi kebutuhan protein hewani. Ayam jantan tipe medium berasal dari hasil samping usaha penetasan ayam petelur. Ayam jantan tipe medium di penetasan merupakan hasil yang tidak diharapkan, karena hanya ayam betina yang dipasarkan untuk diambil produksi telurnya.

Ayam jantan tipe medium mempunyai potensi untuk digunakan sebagai penghasil daging. Hal ini karena ayam jantan tipe medium memiliki kadar lemaknya lebih rendah dibandingkan dengan broiler. Daryanti (1982) menyatakan bahwa persentase lemak ayam jantan tipe Harco dan Dekalb pada umur 6 minggu adalah 2,36\% dan 3,30\%. Persentase lemak ini masih rendah daripada persentase lemak broiler umur 6 minggu yaitu 6,65\%.

Pertumbuhan ayam jantan tipe medium dipengaruhi oleh dua faktor yaitu genetik $30 \%$ dan lingkungan $70 \%$. Salah satu keadaan lingkungan yang berpengaruh terhadap pertumbuhan ayam jantan tipe medium adalah suhu udara dalam kandang yang berbeda antara siang dan malam. Menurut Aksi Agraris Kanisius/AAK (2003), perbedaan suhu antara siang dan malam hari cukup tinggi, yaitu berkisar antara 3 dan $5^{\circ} \mathrm{C}$ dengan kisaran suhu harian $26--32^{\circ} \mathrm{C}$.

Masalah yang dihadapi ayam pada umur awal adalah keterbatasan lingkungan dan manajemen pemeliharaan. Ayam seringkali menderita akibat suhu tinggi, kelembaban rendah dan ventilasi yang jelek. Suhu dan kelembaban udara yang tinggi pada siang akan menyebabkan konsumsi air minum meningkat, nafsu makan menurun sehingga konsumsi ransum rendah dan konversi ransum kurang baik. Sebaliknya, suhu dan kelembaban udara yang rendah pada malam akan menyebabkan konsumsi air minum menurun, nafsu makan meningkat sehingga konsumsi ransum tinggi dan konversi ransum menjadi lebih baik.

Untuk mencegah terjadinya pemborosan ransum sebagai akibat dari belum adanya persentase pemberian ransum pada siang dan malam bagi ayam jantan tipe medium di lapangan, perlu dilakukan pemberian ransum sesuai dengan suhu lingkungan. Pada sore hari dan sepanjang malam sampai menjelang pagi hari merupakan suhu harian rendah. Ayam akan merasa nyaman dan akan makan lebih banyak dibandingkan dengan makan pada saat suhu menjelang tengah hari hingga sore hari. Salah satu cara menciptakan suhu yang nyaman bagi ternak dapat menggunakan kandang panggung. Menurut Fadillah (2004), kandang panggung mempunyai ventilasi yang berfungsi lebih baik karena udara bisa masuk 
dari bawah dan samping kandang. Apabila ayam jantan tipe medium dipelihara pada lingkungan yang nyaman, tidak stres, tersedia ransum yang berkualitas dan air minum yang bersih dan ad libitum, ayam bisa tumbuh, berkembang dan berproduksi dengan optimal, sehingga berpengaruh terhadap peningkatan bobot hidup, bobot karkas, dan bobot giblet.

Berdasarkan uraian di atas, penulis melakukan penelitian tentang pengaruh persentase pemberian ransum pada siang dan malam hari terhadap bobot hidup, bobot karkas, dan bobot giblet pada ayam jantan tipe medium di kandang panggung.

\section{Tujuan Penelitian}

Tujuan dari penelitian ini adalah untuk mengetahui pengaruh persentase pemberian ransum pada siang dan malam hari terhadap bobot hidup, bobot karkas, dan bobot giblet ayam jantan tipe medium di kandang panggung sertamengetahui level terbaik persentase pemberian ransum pada siang dan malam hari terhadap bobot hidup, bobot karkas, dan bobot giblet ayam jantan tipe medium di kandang panggung.

\section{METODE PENELITIAN}

\section{Tempat dan Waktu Penelitian}

Penelitian ini dilaksanakan pada 28 November 2011--16 Januari 2012 selama 7 minggu, di kandang panggung milik Rama Jaya Farm, Karang Anyar, Lampung Selatan.

\section{Ayam}

Ayam yang digunakan pada penelitian ini adalah ayam jantan tipe medium strain MB 502 umur 3 minggu sebanyak 288 ekor dengan kepadatan kandang 16 ekor $/ \mathrm{m}^{2}$. Rata-rata bobot awal 109,97 $\pm 10,30 \mathrm{~g} /$ ekor dengan koefisien keragamannya 9,4\%.Untuk karkas diambil ayam umur 7 minggu. Rata-rata bobot panen $771,94 \pm 20,25$ g/ekor dengan koefisien keragamannya $2,6 \%$.

\section{Ransum}

Ransum yang digunakan pada penelitian ini adalah ransum komersial BBR1 (Bestfeed) yang diproduksi PT. J apfa Comfeed Indonesia, Tbk yang diberikan pada umur 149 hari. Kandungan nutrisi ransum disajikan pada Tabel 1.

Tabel 1. Kandungan nutrisi ransum berdasarkan analisis proksimat

\begin{tabular}{lc}
\hline \multicolumn{1}{c}{ Kandungan nutrisi } & BBR-1 (Bestfeed) $(\%)$ \\
\hline Air & 8,97 \\
Protein & 21,70 \\
Lemak & 8,69 \\
Serat kasar & 2,00 \\
Abu & 4,76 \\
Gross energi $(\mathrm{kkal} / \mathrm{kg})^{*}$ & $3.965,08$ \\
Energi metabolis $(\mathrm{kkal} / \mathrm{kg})^{\star *}$ & $3.172,06$ \\
\hline
\end{tabular}

Sumber : Hasil analisis Laboratorium Nutrisi dan Makanan Ternak, Jurusan Peternakan, Fakultas Pertanian, Universitas Lampung (2012).

* Hasil analisis Balai Riset dan Standarisasi Industri Bandar Lampung (2012).

${ }^{* *}$ Hasil perhitungan $80 \%$ dari nilai Gross energi (Schaible, 1980)

Persentase pemberian ransum pada siang dan malam didasarkan pada konsumsi ransum ayam jantan medium yang di pelihara di Rama Jaya Farm disajikan pada Tabel 2. 
Tabel 2. Kebutuhan konsumsi ransum ayam jantan tipe medium di Rama Jaya Farm (g/ekor/hari)

\begin{tabular}{lclllrr}
\hline & \multicolumn{6}{c}{ Perlakuan } \\
\cline { 2 - 7 } Minggu ke- & \multicolumn{3}{c}{ R1 } & \multicolumn{2}{c}{ R2 } \\
\cline { 2 - 7 } & $30 \%$ siang & $70 \%$ malam & $50 \%$ siang & $50 \%$ malam & $\begin{array}{c}50 \% \\
\text { siang }\end{array}$ & $\begin{array}{c}50 \% \\
\text { malam }\end{array}$ \\
\hline 3 & 7,50 & 17,50 & 12,50 & 12,50 & 17,50 & 7,50 \\
4 & 9,30 & 21,70 & 15,50 & 15,50 & 21,70 & 9,30 \\
5 & 11,10 & 25,90 & 18,50 & 18,50 & 25,90 & 11,10 \\
6 & 12,60 & 29,40 & 21,00 & 21,00 & 29,40 & 12,60 \\
7 & 14,10 & 32,90 & 23,50 & 23,50 & 32,90 & 14,10 \\
\hline
\end{tabular}

Sumber : Rama Jaya Farm (2008)

Berdasarkan Tabel 2 maka perlakuan $\mathrm{R} 1=30 \%$ siang : 70\% malam;

$\mathrm{R} 2=50 \%$ siang : $50 \%$ malam; dan $\mathrm{R} 3$ 70\% siang : $30 \%$ malam dari ad libitum dapat dilihat pada Tabel 3

Tabel 3. Perlakuan pemberian ransum berdasarkan konsumsi ransum ayam jantantipe medium di Rama Jaya Farm

\begin{tabular}{cc}
\hline Minggu & $\begin{array}{c}\text { Konsumsi ransum } \\
\text { (g/ekor/hari) }\end{array}$ \\
\hline 1 & 12 \\
2 & 19 \\
3 & 25 \\
4 & 31 \\
5 & 37 \\
6 & 42 \\
7 & 47 \\
\hline
\end{tabular}

\section{Air minum} ad libitum.

Air minum yang digunakan dalam penelitian berupa air sumur yang diberikan secara

\section{Metode penelitian}

Penelitian ini terdiri atas 3 perlakuan yaitu :

$\mathrm{R} 1$ : pemberian ransum $30 \%$ siang dan $70 \%$ malam

R2 : pemberian ransum $50 \%$ siang dan $50 \%$ malam

R3 : pemberian ransum $70 \%$ siang dan $30 \%$ malam

Penelitian ini menggunakan metode rancangan acak lengkap (RAL) dengan 3 perlakuan dan 6 ulangan. Variabel yang diukur antara lain adalah bobot hidup, bobot karkas dan bobot giblet. Data yang dihasilkan dianalisis dengan analisis ragam. Sebelum dianalisis ragam, data diuji terlebih dahulu dengan uji normalitas, homogenitas, dan aditivitas. Apabila dari analisis ragam menunjukkan bahwa perlakuan terhadap persentase pemberian ransum siang dan malam nyata pada taraf $5 \%$, maka analisis dilanjutkan dengan uji Duncan (Steel and Torrie, 1993).

\section{Bobot hidup}

Untuk mengetahui bobot hidup (g/ekor) dilakukan penimbangan ayam percobaan setelah dipuasakan selama 6 jam (Soeparno, 1998). 


\section{Bobot karkas}

Bobot karkas ( $\mathrm{g}$ ) ditimbang berdasarkan ayam tanpa darah, bulu, kepala sampai batas pangkal leher, kaki sampai batas lutut, dan organ dalam (Ministery ofAgriculture Indonesia, 1998).

\section{Bobot giblet}

Bobot giblet $(\mathrm{g})$ ditimbang berdasarkan bobot hati, jantung, dan gizzard yang telah dibersihkan dari kotoran (Kurtini, dkk., 2011).

\section{HASIL DAN PEMBAHASAN}

\section{Pengaruh Perlakuan terhadap Bobot Hidup Ayam J antan Tipe Medium}

Rata-rata bobot hidup (g/ekor) ayam jantan tipe medium umur 7 minggu pada masing-masing perlakuan dapat dilihat pada Tabel 4 yang berkisar antara 739,167 dan 755,833 g/ekor.

Tabel 4. Bobot hidup ayam jantan tipe medium pada umur 7 minggu (g/ekor)

\begin{tabular}{llll}
\hline Ulangan & \multicolumn{3}{c}{ Perlakuan } \\
\cline { 2 - 4 } 1 & $\mathrm{R} 1$ & $\mathrm{R} 2$ & $\mathrm{R} 3$ \\
\cline { 2 - 4 } 2 & 750 & 755 & 740 \\
3 & 765 & 745 & 745 \\
4 & 765 & 740 & 770 \\
5 & 740 & 770 & 695 \\
6 & 740 & 755 & 750 \\
\hline Jumlah & 735 & 770 & 735 \\
\hline Rata-rata & 4.495 & 4.535 & 4.435 \\
\hline
\end{tabular}

Hasil analisis ragam menunjukkan bahwa persentase pemberian ransum siang dan malam hari berpengaruh tidak nyata $(P>0,05)$ terhadap bobot hidup ayam jantan tipe medium umur 7 minggu. Hal ini diduga karena semua ayam berada pada lingkungan kandang yang sama dan dengan kepadatan yang sama pula disetiap petak kandangnya. Hal ini didukung oleh Aliyani (2002) yang menyatakan bahwa bobot hidup dipengaruhi oleh konsumsi ransum, kualitas ransum, lama pemeliharaan dan aktivitas.

Salah satu keadaan lingkungan yang berpengaruh terhadap pertumbuhan ayam jantan tipe medium adalah suhu udara dalam kandang. Persentase pemberian ransum siang dan malam yang berpengaruh tidak nyata $(P>0,05)$ terhadap bobot hidup diduga pula disebabkan suhu udara dalam kandang. Suhu selama penelitian antara siang dan malam hari tidak jauh berbeda yaitu $\left(27,67^{\circ} \mathrm{C}\right.$ dan $\left.26,40^{\circ} \mathrm{C}\right)$. Suhu pemeliharaan selama penelitian diduga sesuai dengan suhu termonetral untuk ayam jantan tipe medium, sehingga perbedaan persentase pemberian ransum siang dan malam tidak memegaruhi penggunaan nutrisi ransum yang menyebabkan ransum tidak banyak terbuang untuk penyesuaian tubuh terhadap lingkungan. Menurut Medion (2012), suhu yang nyaman untuk ayam ialah $25--28^{\circ} \mathrm{C}$.

Konsumsi ransum pada perlakuan R2 (pemberian ransum $50 \%$ siang dan $50 \%$ malam) sebesar 234,10 g/ekor/minggu (Tabel 10) merupakan konsumsi ransum tertinggi. Konsumsi ransum yang tinggi ternyata diikuti pula oleh bobot hidup yang tinggi pula yaitu 755,833 g/ekor. Hal ini diduga disebabkan oleh persentase pemberian ransum yang diberikan antara siang dan malam relatif sama. Suhu yang nyaman dan tidak jauh berbeda antara siang dan malam yaitu $\left(27,67^{\circ} \mathrm{C}\right.$ dan $\left.26,40^{\circ} \mathrm{C}\right)$ mengakibatkan ransum yang dikonsumsi dapat dipergunakan sebaik mungkin di dalam tubuh. Hal ini sesuai dengan pendapat Cahyono (2004) yang menyatakan bahwa jika fungsi fisiologis ayam tidak terganggu maka ransum yang dikonsumsi akan digunakan sebaik-baiknya untuk pertumbuhan. Menurut Yousef (1985), suhu lingkungan kritis pada unggas $-10^{\circ} \mathrm{C}$ dan $>38^{\circ} \mathrm{C}$. 


\section{Pengaruh Perlakuan terhadap Bobot Karkas Ayam J antan Tipe Medium}

Tabel 5. Bobot karkas ayam jantan tipe medium pada umur 7 minggu

\begin{tabular}{lrrr}
\hline Ulangan & \multicolumn{3}{c}{ Perlakuan } \\
\cline { 2 - 4 } & R1 & R2 & R3 \\
\hline------------- \\
2 & 449,27 & 452,14 & 463,60 \\
3 & 455,64 & 451,40 & 452,49 \\
4 & 441,33 & 452,97 & 475,30 \\
5 & 441,30 & 466,48 & 410,11 \\
6 & 431,42 & 457,37 & 460,60 \\
Jumlah & 423,28 & 472,34 & 455,07 \\
Rata-rata & $2.642,24$ & $2.752,70$ & $2.717,17$ \\
& 440,37 & 458,78 & 452,86 \\
\hline
\end{tabular}

Bobot karkas yang tidak berbeda nyata diduga dipengaruhi oleh bobot hidup yang tidak berbeda nyata pula (Tabel 7). Bobot karkas seekor ayam erat hubungannya dengan bobot hidup ayam waktu panen. Menurut Soeparno (1998), salah satu faktor yang memengaruhi bobot karkas adalah bobot hidup. Selanjutnya ditambahkan oleh Purba (1990), bobot hidup rendah menghasilkan bobot karkas rendah karena komponen utama karkas adalah tulang dan otot.

Rata-rata bobot karkas dengan perlakuan R1 (pemberian ransum 30\% siang dan $70 \%$ malam) 440,37 g/ekor, R2 (pemberian ransum 50\% siang dan 50\% malam) 458,78 g/ekor, dan R3 (pemberian ransum 70\% siang dan 30\% malam) 452,86 g/ekor. Hasil analisis ragam yang tidak berpengaruh nyata $(P>0,05)$ terhadap bobot karkas diduga juga disebabkan oleh suhu lingkungan. Pelaksanaan penelitian ini dilakukan pada saat musim hujan sehingga rata-rata suhu lingkungan antara siang dan malam hari tidak berbeda jauh $\left(27,67^{\circ} \mathrm{C}\right.$ dan $\left.26,40^{\circ} \mathrm{C}\right)$.

Pertumbuhan adalah proses kompleks yang memerlukan koordinasi kerja beberapa hormon. Pada ayam, pertumbuhan diatur oleh hormon pertumbuhan (G rowth hormone) dan hormon tiroid (tiroksin). Persentase pemberian ransum siang dan malam dengan suhu lingkungan yang tidak berbeda jauh antara siang dan malam hari $\left(27,67^{\circ} \mathrm{C}\right.$ dan $26,40^{\circ} \mathrm{C}$ ) mengakibatkan hormon tiroksin yang dihasilkan oleh kelenjar tiroid relatif sama sehingga bobot karkas tidak berbeda. Menurut Farrel (1979), pada saat suhu lingkungan rendah kelenjar tiroid dapat menghasilkan tiroksin secara maksimal. Fungsi utama hormon tiroksin untuk meningkatkan metabolisme dan penyerapan zat-zat nutrisi yang akan meningkatkan absorpsi makanan di usus, dengan demikian laju pertumbuhan akan meningkat.

\section{Pengaruh Perlakuan terhadap Bobot Giblet Ayam J antan Tipe Medium}

Gibletterdiri atas jantung, hati, dan gizzard. Rata-rata bobot giblet (g/ekor) ayam jantan tipe medium umur 7 minggu pada masing-masing perlakuan dapat dilihat pada Tabel 6 yang berkisar antara 32,47 dan 34,11 g/ekor. Hasil analisis ragam (Tabel 9) menunjukkan bahwa persentase pemberian ransum siang dan malam berpengaruh tidak nyata $(P>0,05)$ terhadap bobot giblet ayam jantan tipe medium umur 7 minggu. 
Tabel 6. Bobot giblet ayam jantan tipe medium pada umur 7 minggu (g/ekor)

\begin{tabular}{llll}
\hline Ulangan & \multicolumn{3}{c}{ Perlakuan } \\
\cline { 2 - 4 } & $\mathrm{R} 1$ & $\mathrm{R} 2$ & $\mathrm{R} 3$ \\
\hline 1 & 33,17 & 34,11 & 30,06 \\
2 & 35,62 & 33,00 & 33,75 \\
3 & 36,36 & 32,65 & 33,52 \\
4 & 33,56 & 34,53 & 34,24 \\
5 & 31,54 & 28,76 & 32,91 \\
6 & 34,40 & 31,77 & 30,44 \\
Jumlah & 204,65 & 194,82 & 194,92 \\
\hline Rata-rata & 34,11 & 32,47 & 32,49 \\
\hline
\end{tabular}

Perlakuan persentase pemberian ransum siang dan malam berpengaruh tidak nyata $(P>0,05)$ terhadap bobot giblet. Hal ini diduga disebabkan oleh konsumsi serat kasar pada ayam jantan tipe medium. Rata-rata konsumsi serat kasar dengan persentase pemberian ransum yang berbeda antara siang dan malam yaitu berkisar antara 4,42 dan 4,68 g/ekor/minggu. Aktivitas gizzard akan lebih berat jika menggiling bahan makanan dengan kandungan serat kasar tinggi, sehingga berakibat terhadap bobot gizzard. Konsumsi serat kasar dapat menyebabkan kontraksi dari otot gizzard, jantung, dan hati menjadi lebih sedikit dalam mencerna makanan sehingga bobot giblet menjadi tidak nyata.

Ransum yang diberikan pada masing-masing perlakuan adalah ransum komersial berbentuk crumble dengan kandungan nutrisi yang sama(Tabel 1). Ransum diberikan sesuai dengan perlakuan yaitu R1 (pemberian ransum 30\% siang dan $70 \%$ malam), R2 (pemberian ransum 50\% siang dan $50 \%$ malam), dan R3 (pemberian ransum $70 \%$ siang dan $30 \%$ malam). Penggunaan ransum yang sama dengan kandungan serat kasar sebesar $2 \%$ dan masih dalam batas yang dapat ditoleransi untuk dicerna dalam tubuh ayam. Hal inilah yang menyebabkan bobot giblet berpengaruh tidak nyata terhadap perlakuan persentase pemberian ransum siang dan malam. Menurut Wahju (1992), kandungan serat kasar yang diperbolehkan untuk unggas yaitu tidak lebih dari $6 \%$. Kandungan serat kasar yang sama membuat kerja gizzard dalam mencerna makanan akan sama sehingga bobot giblet yang dihasilkan akan relatif sama.

Rata-rata bobot giblet ayam jantan tipe medium hasil penelitian ini yaitu berturut-turut sebesar R1 (34,11g/ekor), R2 (32,47g/ekor), dan R3 (32,49g/ekor) lebih rendah bila dibandingkan dengan dengan hasil penelitian Rahmadiani (2010) 39,35 g/ekor. Perbedaan ini disebabkan oleh perbedaan rata-rata bobot hidup dan kandungan nutrisi ransum yang digunakan. Pada penelitian Rahmadiani (2010) rata-rata bobot hidup yang digunakan yaitu 660 sampai dengan 750 g/ekor, sedangkan pada penelitian ini rata-rata bobot hidup 739,167 sampai dengan 755,838 g/ekor.

Apabila dilihat dari kandungan nutrisi ransum, serat kasar dari ransum yang digunakan pada penelitian ini berbeda dengan penelitian Rahmadiani (2010). Pada penelitian ini kandungan serat kasar ransum sebesar $2 \%$ sedangkan kandungan serta kasar pada penelitian Rahmadiani (2010) sebesar 5\%. Kandungan serat kasar yang berbeda akan memengaruhi kerja gizzard sehingga akan berpengaruh terhadap bobot giblet.

\section{KESIMPULAN}

Berdasarkan hasil penelitian ini dapat disimpulkan bahwa perlakuan persentase pemberian ransum pada siang dan malam hari menghasilkan pengaruh tidak nyata terhadap bobot hidup, bobot karkas, dan bobot giblet ayam jantan tipe medium umur 7 minggu 


\section{DAFTAR PUSTAKA}

Abidin, Z.2002.Meningkatkan Produktivitas Ayam Ras Petelur.PT. AgroMediaPustaka.Depok.

Aksi Agraris Kanisius.2003.Beternak Ayam Pedaging. Cetakan ke-18. Kanisius. Jakarta.

Aliyani, A. 2002. Persentase Berat Karkas dan Organ dalam Ayam Broiler yangDiberi Tepung Daun Talas (Colocasia esculenta (L.) Schoot) dalam Ransumnya. Skripsi. Fakultas Peternakan. Institut Pertanian Bogor. Bogor.

Balai Riset dan Standarisasi Industri. 2012. Data Hasil AnalisisKalori.Laboratorium Analisis.Lampung.

Cahyono, B.2004. Cara Meningkatkan Budidaya Ayam Ras Pedaging. Cetakan ke-1. Yayasan Pustaka Nusantara. Yogyakarta.

Daryanti. 1982. Perbandingan Komposisi Tubuh Antara Ayam Jantan Petelur Dekalb dan Harco Dengan Ayam Jantan Broiler". Karya IImiah. InstitutPertanian Bogor. Bogor.

Fadillah, R. 2004.Ayam Broiler Komersial. Cetakan ke-2.Agromedia Pustaka. Jakarta.

Farrel, D.J.1979.Pengaruh Dari Suhu Tinggi terhadap Kemampuan Biologis Dari Unggas.Laporan Seminar IImu dan Industri Perunggasan I. Pusat Penelitian dan Pengembangan Ternak.Ciawi.Bogor.

Kurtini, T., K. Nova, dan D. Septinova. 2011.Ilmu Produksi Ternak Unggas. Buku Ajar.Fakultas Pertanian.Universitas Lampung.Bandar Lampung.

Medion.2012.

http://ayamkampung.org/artikel/penyakit-pernapasan-yang-tak- pernah-tuntas-.html. Diakses pada 15 Mei 2012.

Ministery of Agriculture Indonesia, 1998.Processing Poultry. InternationalCourse on Poultry Husbandry. International Traning Center Ciawi. Bogor.

Nova, K., T. Kurtini, dan Riyanti. 2002. Manajemen Usaha Ternak Unggas. Buku Ajar.Fakultas Pertanian.Universitas Lampung. Bandar Lampung.

Parakkasi, A. 1998. Ilmu Gizi dan Makanan Ternak Monogastrik. Cetakan Ke-1. Angkasa. Bandung.

Payne.1970.Cattle Production in The Tropic.Longman Group.London.

Purba, D.K.1990. Perbandingan Karkas dan Nonkarkas pada Ayam Jantan Kampung, Petelur, dan Broiler Umur 6 Minggu. Karya ilmiah. Fakultas ss Peternakan. Institut Pertanian Bogor. Bogor.

Rama Jaya. 2008. Kebutuhan Konsumsi Ransum Ayam jantan Tipe Medium per Ekor. PT. Rama Jaya Farm. Lampung.

Rahmadiani, W. 2010.Pengaruh Kepadatan Kandang terhadap Bobot GibletdanPanjang Usus Ayam Jantan Tipe Medium. Skripsi. Fakultas Pertanian. Universitas Lampung.Bandar Lampung.

Schaible. 1980. Poultry Feed and Nutrition. Dept. of Poultry Sci. Michigan State University, East Lansing. Michigan. 
Soeparno. 1998. Ilmu dan Teknologi Daging. Cetakan ke-2.Gadjah Mada UniversityPress. Yogyakarta.

Steel, R.G.D. dan J. H. Torrie. 1993. Prinsip dan Prosedur Statistika. Diterjemahkan oleh Sumantri, B. PT. Gramedia Pustaka Utama. Jakarta

Wahju, J. 1992. IImu Nutrisi Unggas. Cetakan ke-3. Gadjah Mada University Press.Yogyakarta.

Yahya, A. 2003. Pengaruh Saccharomyces cereviciae dalam Ransum terhadap Pertumbuhan Broiler. Skripsi. Fakultas Pertanian. Universitas Lampung. Bandar Lampung.

Yousef, M. K. 1985. Stress Physiology in Livestock: Basic Principles. Vol 1. CRC Press Inc. Boca Raton. Florida. 


\title{
PENGARUH SISTEM PENGAWINAN (INSE MINASI B UATAN DAN ALAMI) DAN \\ PARITAS INDUK B ABI TERHADAP LITTER SIZE DI USAHA PETERNAKAN BABI PT. ADHI FARM, SOLO
}

\section{THE EFFECT OF MATING SYSTEM (NATURAL AND ARTIFICIAL INSEMINATION) AND PARITY OF SOW ON LITTER SIZE AT PT. ADHI FARM, SOLO}

\author{
Maria Herawati \\ Fakultas Peternakan, Universitas Tulang Bawang Lampung
}

\begin{abstract}
The aims of this study was to determine the optimal litter size which produce from the mating system and the sow parity by noticing the litter size born alive, the age of weaning, litter size at weaning, mortality during the suckling period and litter size at weaning percentage. Fourty one farrowing and weaned sows are used in this research. The first factor is the mating system, included artificial insemination and natural service. The second factor is the parity of the sow ( 1 up to 5 ). The data collected were litter size born alive, the age of the weaning, the weaned litter size, mortality of the suckling period and litter size at weaning percentage.The result showed that the mating system had significant effect $(P<0.05)$ on litter size born alive, but not significantly affected $(P>0.05)$ on the age of the weaning, the litter size at weaning, mortality during the sucling period and litter size at weaning percentage. The parity had significantly effect $(P<0.05)$ on the age of the weaning, but not significantly affected $(P>0.05)$ on the litter size born alive, mortality during the sucling period and litter size at weaning percentage. The interaction between the mating system and the parity was significantly effected $(P<0.05)$ on litter size born alive and litter size at weaning. The natural service on the second parity was produce most optimal litter size.
\end{abstract}

Keywords: Litter size, Mating system, Parity

\section{PENDAHULUAN}

Permasalahan yang dihadapi oleh peternakan Indonesia salah satunya adalah permintaan daging yang terus meningkat melebihi produksi yang dihasilkan. Salah satu penyebabnya adalah rendahnya kemampuan induk untuk menghasilkan jumlah anak yang optimal dalam siklus reproduksinya. Cara untuk mengatasi permasalahan tersebut adalah bagaimana mengusahakandan mengembangkan ternak yang mampu berproduksi dengan cepat.

Ternak babi merupakan ternak yang potensial dikembangkan untuk memenuhi kebutuhan akan daging karena mempunyai kemampuan berkembangbiak yang cepat dalam menghasilkan anak seperindukan yang tinggi (Parakkasi, 1990). Jumlah anak babi yang dilahirkan dan hidup, menentukan banyaknya sapihan yang nanti dapat dijual. Upaya untuk menghasilkan litter size yang tinggi sampai disapih diperlukan manajemen yang baik dalam pengawinan (inseminasi buatan maupun alami), penanganan induk dan anaknya yang lahir, umur penyapihan, pemeliharaan babi sapihan dan memperhatikan paritas induk.

Paritas atau frekuensi ternak dalam melahirkan anak adalah salah satu faktor yang dapat mempengaruhi litter size. Semakin sering induk melahirkan, maka semakin besar litter lahir, mencapai puncak kemudian stabil dan selanjutnya diikuti penurunan secara bertahap (Toelihere, 1993). Salah satu usaha untuk meningkatkan paritas adalah dengan mempersingkat umur penyapihan dengan harapan anak yang dihasilkan akan semakin banyak atau produktivitas tahunan induk semakin meningkat.

Inseminasi buatan (IB) pada babi belum banyak diterapkan di Indonesia karena adanya pendapat, bahwa jika melakukan IB banyak mengalami kegagalan daripada keberhasilan dibandingkan dengan pengawinan secara alami, padahal jika dilakukan dengan 
baik dan benar, hasilnya akan sama atau bahkan lebih baik dalam hal menghasilkan litter size. Pengurangan penggunaan pejantan di suatu peternakan untuk mengawini babi betina juga mempunyai dampak ekonomis yang lebih baik. Jumlah sel telur yang dapat dibuahi oleh sperma dengan IB ditentukan oleh kualitas sperma (motilitas sperma, abnormalitas sperma), volume pengencer dan nutrisi sperma yang ditambahkan, dan metode pelaksanaan IB. Kualitas sperma yang baik dapat diperoleh dari seleksi pejantan dan hasil evaluasi semen.

Penelitian ini bertujuan untuk mengetahui dan memahami pengaruh sistem pengawinan (IB dan alami) dan paritas induk terhadap litter size. Selan itu, penelitian ini juga dapat melihat interaksi antara sistem pengawinan dan paritas induk yang dapat menghasilkan litter size optimal.

\section{HASIL DAN PEMBAHASAN}

\section{Pengaruh Sistem Pengawinan dan Paritas Induk terhadap Litter Size Lahir Hidup}

Rataan litter size lahir hidup berdasarkan sistem pengawinan dan paritas induk babi disajikan pada Tabel 5 . Berdasarkan Tabel 5 dapat dilihat, bahwa rataan litter size lahir hidup sebesar 9,43 $\pm 2,34$ ekor. Rataan litter size lahir hidup dari paritas pertama sampai kelima berturut-turut adalah 9,00; 9,89; 9,56; 9,44 dan 9,27 ekor, sedangkan berdasarkan sistem pengawinan IB dan alami memiliki rataan litter size lahir hidup masing-masing 9,04 dan 9,82 ekor.

Analisa sidik ragam menunjukkan, bahwa paritas tidak berpengaruh nyata $(P>0,05)$ terhadap litter size lahir hidup. Meskipun secara statistik tidak berbeda nyata, pada Tabel 5 memperlihatkan litter size tertinggi terdapat pada paritas kedua dan terus menurun hingga paritas kelima, dan induk pada paritas pertama menghasilkan litter size yang paling rendah dibandingkan dengan paritas lainnya. Hasil ini didukung oleh penelitian Shostak dan Metodiev (1994) yang menyatakan, bahwa parity pertama menghasilkan littersize yang paling sedikit dibandingkan dengan parity selanjutnya. Kecenderungan rendahnya litter size pada induk paritas pertama, disebabkan laju ovulasi yang masih rendah pada babi dara (Sihombing, 1997).

Tabel 1. Pengaruh Sistem Pengawinan dan Paritas Induk terhadap Litter Size Lahir Hidup

\begin{tabular}{|c|c|c|c|c|c|c|}
\hline \multirow{2}{*}{$\begin{array}{l}\text { Paritas } \\
\text { Induk }\end{array}$} & \multicolumn{5}{|c|}{ Sistem Pengawinan } & \multirow[t]{2}{*}{ Rataan } \\
\hline & IB & & $\mathrm{n}$ & Alami & $\mathrm{n}$ & \\
\hline & & & & ------ekor----- & & ---------- \\
\hline 1 & $\begin{array}{l}9,36^{\mathrm{ab}} \\
2,20\end{array}$ & \pm & 60 & $8,63^{b} \pm 2,37$ & 80 & $9,00 \pm 2,30$ \\
\hline 2 & $2,2^{9,45^{\mathrm{ab}}}$ & \pm & 59 & ${ }_{2,15}^{10,31^{\mathrm{a}}}$ & 52 & $9,89 \pm 2,20$ \\
\hline 3 & $\begin{array}{l}9,39^{a b} \\
2,98\end{array}$ & \pm & 49 & $9,72^{\mathrm{ab}} \pm 2,52$ & 33 & $9,56 \pm 2,75$ \\
\hline 4 & $\begin{array}{l}9,00^{\mathrm{ab}} \\
2,73\end{array}$ & \pm & 28 & $9,88^{a b} \pm 2,34$ & 17 & $9,44 \pm 2,27$ \\
\hline 5 & $\begin{array}{l}8,00^{b} \\
2,73\end{array}$ & \pm & 5 & $1,69^{10,54^{a}}$ & 11 & $9,27 \pm 2,21$ \\
\hline Rataan & $\begin{array}{c}9,04^{b} \\
2,46\end{array}$ & \pm & & $9,82^{a} \pm 2,21$ & & $9,43 \pm 2,34$ \\
\hline
\end{tabular}

Keterangan:

$\mathrm{n}=$ jumlah pengamatan

Superskrip huruf kecil yang berbeda pada baris atau kolom yang sama menunjukkan perbedaan nyata $(\mathrm{P}<0,05)$

Hasil analisa sidik ragam menunjukkan, bahwa sistem pengawinan ber-pengaruh nyata $(P<0,05)$ terhadap litter size lahir hidup. Tabel 5 menunjukkan, bahwa sistem pengawinan secara alami menghasilkan littersize lahir hidup nyata $(P<0,05)$ lebih tinggi $(9,82$ ekor) dibandingkan dengan IB (9,04 ekor). Hal ini menyatakan, bahwa pengawinan secara alami pada babi lebih baik dibandingkan dengan IB untuk menghasilkan litter size lahir hidup. 
Hasil penelitian ini didukung oleh Sterle dan Safranski (2005) dan McIntosh (2005), bahwa dalam pelaksanaan IB terdapat faktor-faktor kendala untuk keberhasilan IB seperti lingkungan dan manusia.

Hasil analisis ragam menunjukkan, bahwa interaksi antara sistem pengawinan dengan paritas berpengaruh nyata $(P<0,05)$ terhadap litter size lahir hidup. Litter size lahir hidup tertinggi diperoleh pada pengawinan secara alami di paritas kelima (A-P5) yaitu 10,54 ekor, berbeda nyata dengan paritas pertama pada sistem pengawinan yang sama $(8,63$ ekor) dan paritas kelima pada sistem pengawinan IB (8,00 ekor), namun nilai A-P5 lebih tinggi sedikit dibandingkan paritas kedua pada pengawinan yang sama (10,31 ekor), dan tidak berbeda dengan paritas ketiga dan keempat masing-masing 9,72 dan 9,88 ekor. Litter size lahir hidup berdasarkan sistem pengawinan dan paritas induk diperlihatkan pada Gambar 1.

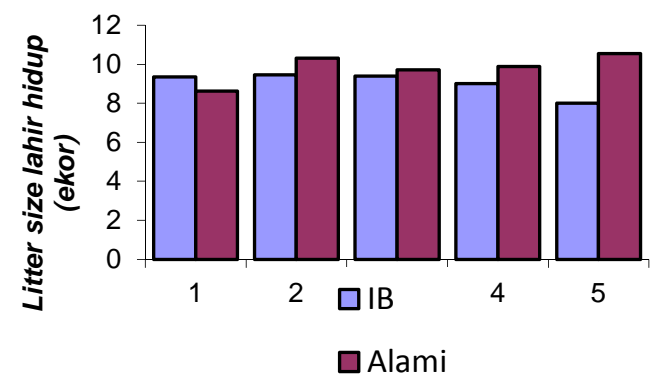

Gambar 1. Grafik Litter Size Lahir Hidup Berdasarkan Sistem Pengawinan dan Paritas Induk

Litter size lahir hidup pada Gambar 3 memperlihatkan, hasil pengawinan secara alami selalu lebih tinggi dibandingkan dengan IB pada semua paritas kecuali pada paritas pertama. Diduga hal ini karena peternak melakukan pengawinan IB pada babi dara sehingga laju pembuahan berikutnya semakin menurun dan berpengaruh terhadap litter size lahir hidup. Menurut Siagian (1999), bahwa pengawinan IB pada babi dara tidak dilakukan mengingat laju pembuahan sangat penting untuk menentukan litter size lahir.

\section{Pengaruh Sistem Pengawinan dan Paritas Induk terhadap Umur Penyapihan}

Rataan umur penyapihan berdasarkan sistem pengawinan dan paritas induk adalah $32,91 \pm 5,14$ hari. Berdasarkan Tabel 6, rataan umur penyapihan dari paritas pertama sampai kelima secara berturut-turut adalah 32,30; 33,16; 32,34; 35,37 dan 31,39 hari, sedangkan sistem pengawinan secara IB dan alami memiliki rataan umur penyapihan masing-masing 32,71 dan 33,11 hari.

Hasil analisa sidik ragam menunjukkan, bahwa paritas berpengaruh nyata $(P<0,05)$ terhadap umur penyapihan. Umur penyapihan pada paritas keempat, nyata $(P<0,05)$ lebih lama dibandingkan paritas pertama (32,30 hari), ketiga (32,34 hari) dan kelima (31,39 hari), tetapi tidak nyata dengan paritas kedua $(33,16$ hari).

Tabel 2. Pengaruh Sistem Pengawinan dan Paritas Induk terhadap Umur Penyapihan

\begin{tabular}{|c|c|c|c|c|c|}
\hline \multirow{2}{*}{$\begin{array}{l}\text { Paritas } \\
\text { Induk }\end{array}$} & \multicolumn{4}{|c|}{ Sistem Pengawinan } & \multirow[t]{2}{*}{ Rataan } \\
\hline & IB & $\mathrm{n}$ & Alami & $\mathrm{n}$ & \\
\hline & & & -----hari ---- & & --------- \\
\hline 1 & $31,61 \pm 4,61$ & 59 & $32,99 \pm 5,60$ & 76 & $32,30^{\mathrm{b}} \pm 5,10$ \\
\hline 2 & $32,83 \pm 5,06$ & 58 & $33,50 \pm 4,67$ & 50 & $33,16^{a b} \pm 4,86$ \\
\hline 3 & $32,46 \pm 4,74$ & 48 & $32,21 \pm 4,09$ & 28 & $32,34^{b} \pm 4,41$ \\
\hline 4 & $35,67 \pm 5,29$ & 24 & $35,08 \pm 4,74$ & 12 & $35,37^{a} \pm 5,01$ \\
\hline 5 & $31,00 \pm 6,06$ & 4 & $31,78 \pm 6,53$ & 9 & $31,39^{b} \pm 6,29$ \\
\hline Rataan & $32,71 \pm 5,15$ & & $33,11 \pm 5,13$ & & $32,91 \pm 5,14$ \\
\hline
\end{tabular}

Keterangan:

$\mathrm{n}=$ jumlah pengamatan (ekor) 
Superskrip huruf kecil yang berbeda pada kolom yang sama menunjukkan perbedaan nyata $(P<0,05)$

Hasil analisa sidik ragam, menunjukkan bahwa sistem pengawinan tidak berpengaruh nyata $(P>0,05)$ terhadap umur penyapihan. Meskipun demikian, umur penyapihan pada pengawinan secara alami lebih lama (33,11 hari) dibandingkan dengan IB (32,71 hari).

Interaksi antara sistem pengawinan dengan paritas tidak berpengaruh nyata $(P>0,05)$ terhadap umur penyapihan. Grafik masa menyusu atau umur penyapihan berdasarkan sistem pengawinan dengan paritas induk diperlihatkan pada Gambar 2.

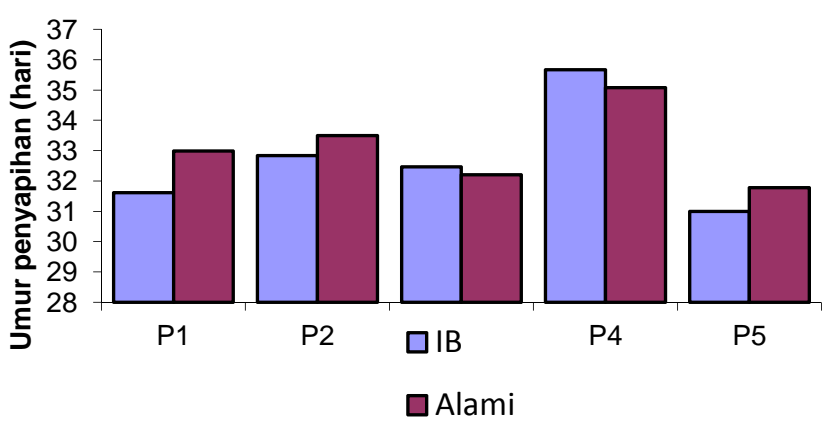
Induk

Gambar 2. Grafik Umur Penyapihan Berdasarkan Sistem Pengawinan dan Paritas

Umur penyapihan dengan sistem pengawinan yang berbeda (IB dengan alami) pada tiap paritas tidak menentu. Hal ini erat kaitannya dengan tata laksana penyapihan yang dilakukan oleh peternak tersebut. Umumnya penyapihan dilakukan pada umur empat minggu, pada hari tertentu dan secara berkelompok. Pengelompokan dilakukan agar induk dapat berahi dan dikawinkan kembali secara bersama-sama. Umur anak babi sudah mencukupi umur penyapihan, namun karena jumlah induk yang menyapih belum banyak, maka ada umur penyapihan diatas umur yang telah ditentukan oleh peternak.

\section{Pengaruh Sistem Pengawinan dan Paritas Induk terhadap Litter Size Sapih}

Rataan litter size sapih berdasarkan sistem pengawinan dan paritas induk adalah $8,26 \pm 1,88$ ekor. Tabel 7 memperlihatkan rataan litter size sapih dari paritas pertama sampai kelima secara berturut-turut adalah 7,96; 8,54; 8,37; 7,99 dan 8,43 ekor, sedangkan litter size sapih berdasarkan sistem pengawinan secara IB dan alami masing-masing 8,06 dan 8,47 ekor.

Tabel 3. Pengaruh Sistem Pengawinan dan Paritas Induk terhadap Litter Size Sapih

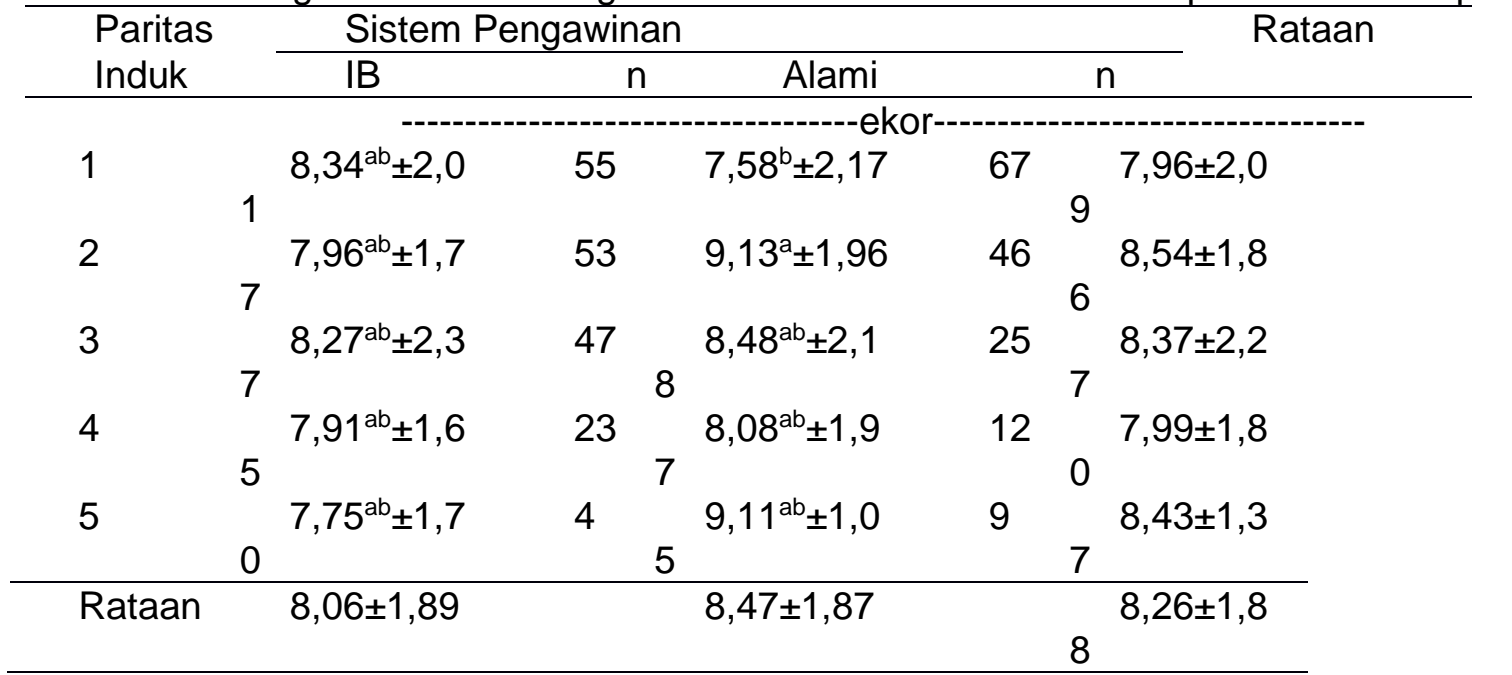

Keterangan:

$\mathrm{n}=$ jumlah pengamatan (ekor) 
Superskrip huruf kecil yang berbeda pada baris atau kolom yang sama menunjukkan perbedaan nyata $(\mathrm{P}<0,05)$

Hasil analisis ragam menunjukkan, bahwa paritas tidak berpengaruh nyata $(P>0,05)$ terhadap litter size sapih. Meskipun secara statistik tidak berbeda nyata, mulai terjadi penurunan litter size sapih pada paritas ketiga dan keempat dibandingkan dengan paritas kedua lalu kembali naik pada paritas kelima. Diduga hal ini disebabkan oleh daya hidup anak yang semakin menurun akibat terlalu lama disapih. Hal ini dibuktikan pada paritas kelima, dimana umur penyapihannya lebih singkat (31,39 hari), menghasilkan litter size sapih yang relatif lebih banyak (8,43 ekor) dibandingkan pada paritas keempat (7,99 ekor) dan ketiga (8,37 ekor). Induk pada paritas pertama menghasilkan litter size sapih (7,96 ekor) paling sedikit dibandingkan paritas lainnya. Hal ini dapat disebabkan litter size lahir hidup pada paritas pertama (9,00 ekor) juga paling rendah sehingga litter size sapih yang dihasilkan paling sedikit dibandingkan paritas lainnya. Pernyataan ini didukung oleh Chabo et al. (1999), bahwa litter size pada saat sapih dipengaruhi oleh banyaknya anak seekor induk per kelahiran.

Hasil analisis ragam menunjukkan, bahwa sistem pengawinan tidak berpengaruh nyata $(P>0,05)$ terhadap litter size sapih. Meskipun demikian, sistem pengawinan secara alami ( 8,47 ekor) lebih banyak menghasilkan litter size sapih daripada IB (8,06 ekor). Tujuan dari penggunaan sistem pengawinan secara IB salah satunya adalah mencegah penularan penyakit, namun apabila tidak diawasi dengan baik maka penyebaran penyakit menular semakin cepat (Toelihere, 1993). Penyakit yang dapat disebarkan oleh semen cair yang tidak ditambahkan dengan antibiotik seperti disentri dan pnemonia (Siagian, 1999) dapat berpengaruh terhadap daya hidup anak babi dan litter size sapih yang dihasilkan.

Hasil analisis ragam menunjukkan, bahwa interaksi antara sistem pengawinan dengan paritas induk berpengaruh nyata $(P<0,05)$ terhadap litter size sapih. Litter size sapih tertinggi diperoleh pada pengawinan secara alami di paritas kedua $(9,13$ ekor), berbeda nyata dengan paritas pertama pada sistem pengawinan yang sama (7,58 ekor) dan tidak berbeda nyata dengan perlakuan lainnya.

Litter size sapih pada Gambar 3 memperlihatkan, bahwa dengan sistem pengawinan secara alami selalu lebih tinggi daripada IB pada semua paritas kecuali paritas pertama yang menghasilkan litter size sapih lebih tinggi pada pengawinan IB. Hal ini berarti litter size sapih erat kaitannya dengan litter size lahir hidup yang dihasilkan. Semakin banyak litter size lahir hidup maka makin banyak litter size sapih yang dihasilkan, sebaliknya semakin sedikit litter size lahir hidup yang dihasilkan maka makin sedikit litter size sapih.

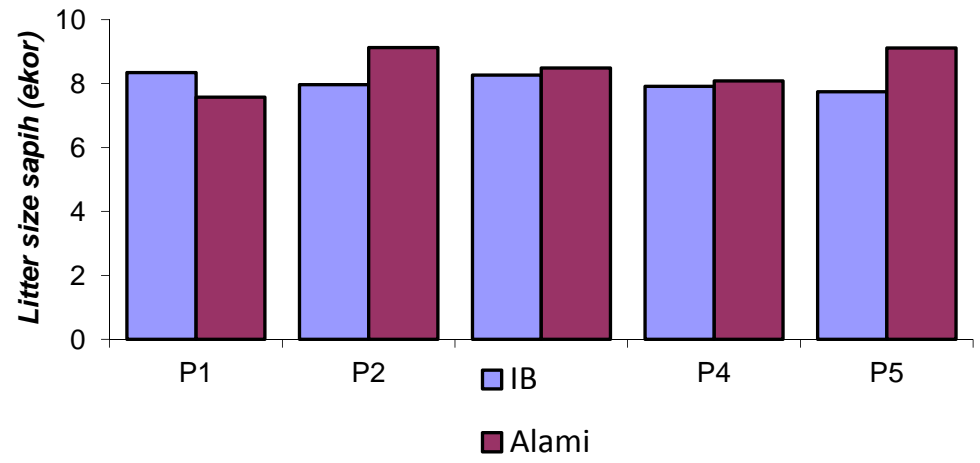

Gambar 3. Grafik Litter Size Sapih Berdasarkan Sistem Pengawinan dan Paritas Induk

\section{Pengaruh Sistem Pengawinan dan Paritas Induk terhadap Persentase Litter Size Sapih}

Rataan persentase litter size sapih berdasarkan sistem pengawinan dan paritas induk adalah $87,85 \pm 13,65 \%$. Tabel 4 memperlihatkan rataan persentase litter size sapih dari paritas pertama sampai kelima secara berturut-turut adalah $88,23 \%$; $87,18 \% ; 87,52 \%$; 
$88,11 \%$ dan $88,22 \%$, sedangkan sistem pengawinan secara IB dan alami masing-masing $88,20 \%$ dan $87,50 \%$.

Hasil analisa sidik ragam menunjukkan, bahwa paritas tidak berpengaruh nyata $(P>0,05)$ terhadap persentase litter size sapih. Meskipun demikian, persentase litter size sapih yang tertinggi yaitu pada paritas pertama $(88,23 \%)$ dan terendah pada paritas kedua $(87,18 \%)$. Paritas pertama dengan litter size lahir hidup paling rendah (9,10 ekor), umur penyapihan 32,30 hari, mortalitas anak babi menyusu sebesar $11,75 \%$ dan persentase litter size sapih yang paling tinggi ternyata menghasilkan litter size sapih paling rendah dibandingkan paritas lainnya (7,96 ekor). Sebaliknya, pada paritas kedua dengan litter size lahir hidup paling tinggi (9,94 ekor), umur penyapihan 33,16 hari, mortalitas anak babi menyusu sebesar $12,77 \%$ dan persentase litter size sapih terendah, ternyata masih mampu menghasilkan litter size sapih paling tinggi dibandingkan paritas yang lain (8,54 ekor).

Tabel 4. Pengaruh Sistem Pengawinan dan Paritas Induk terhadap Persentase Litter Size Sapih

\begin{tabular}{|c|c|c|c|c|c|}
\hline \multirow{2}{*}{$\begin{array}{l}\text { Paritas } \\
\text { Induk }\end{array}$} & \multicolumn{4}{|c|}{ Sistem Pengawinan } & \multirow{2}{*}{ Rataan } \\
\hline & IB & $\mathrm{n}$ & Alami & $\mathrm{n}$ & \\
\hline 1 & $89,93 \pm 11,30$ & 55 & $86,54 \pm 14,67$ & 67 & $88,23 \pm 12,9$ \\
\hline 2 & $85,87 \pm 14,13$ & 53 & $88,49 \pm 13,29$ & 46 & $87,18 \pm 13,7$ \\
\hline 3 & $88,21 \pm 11,24$ & 47 & $86,84 \pm 12,88$ & 25 & $87,52 \pm 12,0$ \\
\hline 4 & $89,67 \pm 15,44$ & 23 & $86,55 \pm 14,37$ & 12 & $88,11 \pm 14,9$ \\
\hline 5 & $87,33 \pm 17,11$ & 4 & $89,11 \pm 12,11$ & 9 & $88,22 \pm 14,6$ \\
\hline Rataan & $88,20 \pm 13,85$ & & $87,50 \pm 13,46$ & & $87,85 \pm 13,6$ \\
\hline
\end{tabular}

Keterangan:

$\mathrm{n}=$ jumlah pengamatan (ekor)

Hasil analisis ragam menunjukkan, bahwa sistem pengawinan tidak berpengaruh nyata $(P>0,05)$ terhadap persentase litter size sapih. Meskipun tidak berbeda secara statistik, persentase litter size sapih hasil IB lebih tinggi $(88,20 \%)$ dibandingkan dengan alami $(87,50 \%)$. Pengawinan secara alami yang menghasilkan litter size lahir lebih tinggi $(9,82$ ekor), umur penyapihan 33,11 hari, mortalitas yang tinggi (12,48\%) dan persentase litter size sapih yang lebih rendah dibandingkan IB, ternyata masih menghasilkan litter size sapih $(8,47$ ekor) yang lebih tinggi dibandingkan dengan IB (8,06 ekor).

Interaksi antara sistem pengawinan dan paritas tidak memberikan pengaruh yang nyata $(P>0,05)$ terhadap persentase litter size sapih. Grafik persentase litter size sapih berdasarkan sistem pengawinan dan paritas induk disajikan pada Gambar 4.

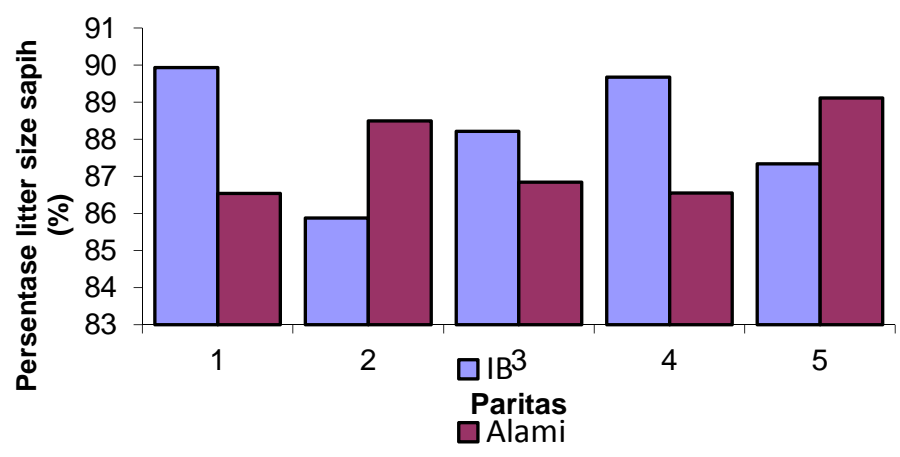

Gambar 4. Grafik Persentase Litter Size Sapih Berdasarkan Sistem Pengawinan dan Paritas Induk 
Gambar 8 memperlihatkan persentase litter size sapih dengan sistem pengawinan yang berbeda (IB dan alami) pada tiap paritas induk tidak menentu. Hal ini dapat dipengaruhi oleh litter size lahir hidup dan litter size sapih (Gambar 9). Persentase litter size sapih tertinggi adalah pengawinan IB pada paritas pertama (IB-P1) yaitu 89,93\%. Perlakuan IB-P1 menghasilkan litter size lahir hidup dan litter size sapih masing-masing sebesar 9,38 dan 8,34 ekor. Litter size sapih tertinggi diperoleh dari pengawinan secara alami pada paritas kedua (A-P2), namun persentase litter size sapih hanya $88,49 \%$. Hal ini menunjukkan, bahwa tingginya persentase litter size sapih belum tentu menjamin litter size sapih yang dihasilkan juga lebih ban

\section{DAFTAR PUSTAKA}

Chabo, R.G., P. Malope dan B. Babusi. 1999. Department of Animal Science and Production Botswana Collage of Agriculture. Available at http:// www.cipav.org.co/irrd/1rrd12/2/cha $123 \mathrm{htm}$.[18 Oktober 2005].

Mclntosh, B. 2005. Mclntosh AB consultans. Available at http:// www.dbi.glg.gov.au/pigs/4555.html. [18 Oktober 2005].

Siagian, P.H. 1999. Manajemen Ternak Babi. Jurusan IImu Produksi Ternak. Institut Pertanian Bogor.

Sihombing, D.T. H. 1997. Ilmu Ternak Babi. Gadjah Mada University Press, Yogyakarta.

Toelihere, M.R. 1993. Inseminasi Buatan pada Ternak. Angkasa, Bandung. 


\title{
Pengaruh Indeks Sinkronisasi dalam Rumen pada Ransum Berbasis Bagase terhadap Produksi VFA Rumen pada Domba
}

\section{Effects of Synchronization Index in the Sugarcane Bagasse Based Ration on the Volatile Fatty Acid Production of Sheep}

\author{
Novi Eka Wati \\ Fakultas Peternakan, Universitas Tulang Bawang Lampung. J I. Gajah Mada No.34 Kotabaru, \\ Bandar Lampung \\ novi.ekawati1990@utb.ac.id
}

\begin{abstract}
The aim of the research was to study the effects of synchronization index in the sugarcane bagasse based ration on acetate, propionate and butirate production of sheep. Two permanent cannulated male local sheep was 2 years old for sampling rumens fluids. They were feed a complete feed based on bagasse with a level of synchrony index 0,37 ; 0,$50 ; 0,63$ were design isoprotein and isoenergy. Each experimental diet was offered to each sheep three times randomly for 7 days, with 7 days interval between feeding period of each experimental diet. About $10 \mathrm{ml}$ of rumen fluid sample were collected before feeding and 3 hour after feeding at the 7th day of each feeding trial period. The alteration of synchronization indexs did not affect acetate, propionate, butirate and ratio acetate/propionate (C2/C3) in rumen before feeding and 3 hour after feeding.
\end{abstract}

Key words : acetate, butirat, propionate, synchrony index

\section{PENDAHULUAN}

Bagase adalah hasil samping tanaman tebu yang dapat dimanfaatkan sebagai sumber serat bagi ruminansia. Bagase potensial sebagai pengganti hijauan karena ketersediaannya melimpah, namun pemanfaatannya dalam ransum terbatas karena NDF yang tinggi sebesar $86,87 \%$ dan kandungan protein kasar yang rendah sebesar $1,45 \%$ (Sani et al., 2012). Penyusunan ransum bagi ternak ruminansia dilakukan berdasarkan kecukupan kebutuhan nutrien untuk mendukung sintesis protein mikrobia dalam rumen. Sintesis protein mikrobia sangat penting bagi ternak ruminansia karena sumber protein pada ruminansia lebih dari $60 \%$ dipenuhi oleh protein mikrobia dalam rumen. Kondisi yang ideal bagi sintesis protein mikrobia dalam rumen adalah prekusor nitrogen merupakan hasil degradasi protein di dalam rumen berupa $\mathrm{NH}_{3}$ dan dan karbon merupakan hasil degradasi karbohidrat berupa VFA. VFA (volatile fatty acid) berupa asam asetat $\left(\mathrm{C}_{2}\right)$, asam propionat $\left(\mathrm{C}_{3}\right)$ dan asam butirat $\left(\mathrm{C}_{4}\right)$ sebagai sumber energi bagi mikrobia dalam rumen (Rahmadi et al., 2010).

Sintesis protein mikrobia yang maksimal dapat dicapai dengan adanya sinkronisasi antara pasokan energi dan protein pakan berdasarkan tingkat degradabilitasnya di dalam 
rumen sehingga waktu pelepasan VFA dan $\mathrm{NH}_{3}$ yang sinkron dan jumlahnya mencukupi. Sinkronisasi antara pasokan energi dan protein dinyatakan dalam indeks sinkronisasi yang merupakan rasio antara $\mathrm{N}$ terdegradasi dengan $\mathrm{BO}$ terdegradasi di dalam rumen yang diukur secara in sacco. Nilai indeks sinkronisasi sebesar 1 menunjukkan sinkronisasi sempurna antara pasokan protein dan energi dalam satu satuan waktu, sehingga nilai indeks sinkronisasi dalam ransum semakin mendekati 1,0 mengindikasikan bahwa tingkat kesinkronan semakin tinggi (Hermon et al., 2008), (Sinclair et al., 1993). Nilai indeks sinkronisasi perlu dipertimbangkan dalam penyusunan ransum agar terjadi keseimbangan antara produksi VFA dan $\mathrm{NH}_{3}$ dalam rumen sehingga sintesis protein mikrobia dalam rumen maksimal dan ketersediaan asam amino bagi ternak meningkat. Tujuan penelitian adalah mengkaji pengaruh pemberian ransum berbasis bagase dengan sinkronisasi pasokan energi dan nitrogen dalam rumen terhadap produksi asetat, propionat dan butirat di dalam rumen serta rasio asam asetat/propionat.

\section{MATERI DAN METODE}

Materi yang digunakan dalam penelitian ini adalah dua ekor domba jantan berfistula berumur \pm 2 tahun. Pakan yang diberikan berupa ransum berbasis bagase yang disusun isoprotein dan iso energi dengan index sinkronisasi sebesar 0,37 (P1), 0,50 (P2) dan 0,63 (P3). Formulasi ransum perlakuan dan kandungan nutrien ransum perlakuan tersaji dalam Tabel 1.

Adaptasi pakan dan lingkungan dilakukan selama 4 minggu dan perlakuan pakan dilakukan selama 8 minggu. Setiap ransum perlakuan diberikan pada semua domba selama 7 hari secara acak. Domba dikandangkan dalam kandang metabolik individual dan diberi minum secara ad libitum terukur. Cairan rumen diambil dari fistula domba sebelum pemberian pakan dan 3 jam setelah pemberian pakan pada hari ke 7 perlakuan. Cairan rumen yang diambil dimasukkan kedalam botol dan ditambahkan $\mathrm{HgCl}_{2} \mathrm{H}_{3} \mathrm{PO}_{4}$ sebagai pengawet dengan perbandingan 1:10. Konsentrasi asetat, propionat dan butirat dianalisis dengan metode gas kromatografi (AOAC, 1995). Data dianalisis dengan ANOVA, jika terdapat pengaruh nyata dilanjutkan dengan uji DMRT untuk mengetahui perbedaan antar perlakuan (Steel and Torrie, 1981).

Tabel 1. Formulasi dan Kandungan Nutrien Ransum Perlakuan

\begin{tabular}{lccc}
\hline \multirow{2}{*}{ Komposisi Ransum } & \multicolumn{3}{c}{ Perlakuan Indeks Sinkronisasi } \\
\cline { 2 - 4 } Komponen Bahan & P1 & P2 & P3 \\
Bagase & 25,00 & 25,00 & 25,00 \\
Dedak & 2,50 & 4,00 & 5,60 \\
Tetes & 2,00 & 4,00 & 7,00 \\
Bungkil kelapa & 2,50 & 6,00 & 16,30
\end{tabular}




\begin{tabular}{|c|c|c|c|}
\hline Urea & 0,70 & 0,50 & 0,20 \\
\hline Bungkil Sawit & 16,50 & 9,00 & 1,00 \\
\hline Kulit kopi & 2,30 & 2,00 & 3,80 \\
\hline Onggok & 30,20 & 15,50 & 2,20 \\
\hline Pollard & 1,10 & 15,50 & 23,00 \\
\hline Kulit kacang & 1,60 & 3,50 & 3,60 \\
\hline Jagung & 5,80 & 4,50 & 0,50 \\
\hline Bungkil Kedelai & 11,30 & 10,00 & 11,30 \\
\hline \multicolumn{4}{|l|}{ Kandungan Nutrisi } \\
\hline bu & 4,36 & 4,97 & 5,87 \\
\hline 3ahan organik & 95,64 & 95,03 & 94,13 \\
\hline rotein kasar & 12,06 & 12,17 & 12,95 \\
\hline emak kasar & 3,37 & 3,44 & 3,70 \\
\hline erat kasar & 25,30 & 24,60 & 25,32 \\
\hline ETN & 54,91 & 54,82 & 52,16 \\
\hline DN & 62,05 & 62,93 & 62,96 \\
\hline JDF & 54,80 & 55,97 & 55,98 \\
\hline DF & 32,85 & 32,12 & 31,67 \\
\hline si sel & 45,20 & 44,03 & 44,02 \\
\hline arbohidrat $(\mathrm{KH})$ & 80,21 & 79,42 & 77,48 \\
\hline Karbohidrat non struktural (KH NS) & 25,41 & 23,45 & 21,50 \\
\hline lemiselulosa & 21,95 & 23,84 & 24,31 \\
\hline
\end{tabular}

\section{HASIL DAN PEMBAHASAN}

Level indeks sinkronisasi ransum tidak memberikan pengaruh nyata $(P>0,05)$ terhadap produksi asam asetat, asam propionat dan asam butirat di dalam rumen domba pada 0 jam (sebelum pemberian pakan) maupun 3 jam setelah pemberian pakan. Prosuksi asam asetat, propionat, butirat dan rasio C2/C3 tersaji dalam tabel 2.

Tabel 2. Produksi Asam Asetat, Asam Propionat, Asam Butirat dan Rasio C2/C3

\begin{tabular}{|c|c|c|c|c|c|}
\hline \multirow{3}{*}{ Parameters } & \multirow{3}{*}{ Jam } & \multicolumn{3}{|c|}{ Diet } & \multirow{3}{*}{ Ket } \\
\hline & & P1 & P2 & P3 & \\
\hline & & \multicolumn{3}{|c|}{------------------------'mM--------------------- } & \\
\hline \multirow[t]{2}{*}{ Asam Asetat (C2) } & 0 & $26,13 \pm 0,32$ & $27,27 \pm 0,32$ & $26,43 \pm 0,32$ & ns \\
\hline & 3 & $44,77 \pm 2,69$ & $45,00 \pm 2,69$ & $47,33 \pm 2,69$ & ns \\
\hline \multirow[t]{2}{*}{ Asam Propionat (C3) } & 0 & $13,51 \pm 0,29$ & $14,72 \pm 0,29$ & $14,72 \pm 0,29$ & ns \\
\hline & 3 & $21,97 \pm 2,14$ & $23,41 \pm 2,14$ & $28,40 \pm 2,14$ & ns \\
\hline \multirow[t]{2}{*}{ Asam Butirat (C4) } & 0 & $7,28 \pm 0,20$ & $7,80 \pm 0,20$ & $7,64 \pm 0,20$ & ns \\
\hline & 3 & $4,16 \pm 0,34$ & $3,74 \pm 0,34$ & $3,97 \pm 0,34$ & ns \\
\hline \multirow[t]{2}{*}{ Rasio C2/C3 } & 0 & $1,93 \pm 0,05$ & $1,85 \pm 0,05$ & $1,87 \pm 0,05$ & ns \\
\hline & 3 & $2,06 \pm 0,13$ & $1,92 \pm 0,13$ & $1,71 \pm 0,13$ & ns \\
\hline
\end{tabular}

Keterangan: $\quad$ ns $=$ tidak berbeda nyata $(P>0,05)$

Nilai tersebut merupakan rata-rata dari 4 ulangan \pm sd 
Produksi asam asetat rumen domba sebelum pemberian ransum dan 3 jam setelah pemberian ransum perlakuan tidak berbeda nyata $(P>0,05)$ pada ransum $P 1, P 2$ dan $P 3$. Hal ini tidak sesuai dengan hasil penelitian Seo et al., (2010) bahwa level indeks sinkronisasi ransum sapi Holstein yang semakin tinggi menghasilkan konsentrasi asam asetat, propionat dan butirat yang semakin tinggi. Produksi asam asetat meningkat dari sebelum pemberian ransum hingga 3 jam setelah pemberian ransum. Peningkatan produksi asam asetat disebabkan adanya proses fermentasi serat yang terkandung di dalam ransum perlakuan.

Produksi asam propionat rumen domba sebelum pemberian ransum dan 3 jam setelah pemberian ransum perlakuan tidak berbeda nyata $(P>0,05)$ pada ransum $P 1, P 2$ dan P3. Produksi asam propionat meningkat dari sebelum pemberian ransum hingga 3 jam setelah pemberian ransum. Hal ini disebabkan adanya proses fermentasi karbohidrat di dalam rumen dan adanya pemecahan asam laktat dan didegradasi di dalam rumen menjadi asam propionat. Zamillah et al. (2011) menyatakan bahwa propionat akan diabsorbsi masuk dalam darah, menuju ke hati dan diubah menjadi glukosa darah sebagai sumber energi untuk ruminansia.

Produksi asam butirat rumen domba sebelum pemberian ransum dan 3 jam setelah pemberian ransum perlakuan tidak berbeda nyata $(P>0,05)$ pada ransum $P 1, P 2$ dan $P 3$. Produksi asam butirat rumen domba yang diberi ransum $\mathrm{P} 1, \mathrm{P} 2$ dan $\mathrm{P} 3$ cenderung menurun dari sebelum pemberian ransum hingga 3 jam setelah pemberian ransum. Hal ini disebabkan karena asam butirat memiliki sifat absorbsi oleh dinding rumen yang lebih cepat dibandingkan asam asetat dan propionat. Sesuai pendapat Pamungkas et al. (2008) bahwa propionat dan asetat mempunyai sifat absorbsi yang lebih lambat dibanding butirat yang memiliki jumlah yang sedikit. Richardson et al. (2003) menyatakan bahwa peningkatan level indeks sinkronisasi ransum menghasilkan konsentrasi asetat, propionat, butirat dalam rumen yang tidak signifikan.

Rasio C2/C3 rumen domba sebelum pemberian ransum dan 3 jam setelah pemberian ransum perlakuan tidak berbeda nyata $(P>0,05)$ pada domba yang diberi ransum P1, P2 dan P3. Rasio asetat dan propionat yang sama pada hasil penelitian diduga disebabkan oleh kandungan karbohidrat yang sama antar perlakuan. Arora (1995) menyatakan bahwa konsentrasi VFA rumen dipengaruhi oleh konsumsi karbohidrat yang terdiri dari serat dan BETN. Kandungan BETN ransum perlakuan P1, P2 dan P3 sama yaitu sebesar 54,91\%, 54,82\% dan 52,16\%. Besarnya kandungan NDF ransum P1, P2 dan P3 sama yaitu 54,80\%,55,97\% dan 55,98\%. Hal ini mengakibatkan besarnya konsentrasi asetat dan propionat pada 0 dan 3 jam setelah pemberian pakan tidak berbeda nyata sehingga rasio asetat dan propionat tidak berbeda nyata. Rasio C2/C3 pada rumen domba yang diberi ransum P1 dan P2 cenderung meningkat dari sebelum pemberian ransum hingga 3 jam setelah pemberian ransum perlakuan, sedangkan pada P3 cenderung menurun. Menurut pendapat Piao et al., (2012) dan Wati et al., (2015), peningkatan level 
indeks sinkronisasi ransum menghasilkan rasio asetat dan propionat dalam rumen dan glukosa darah yang tidak signifikan.

\section{KESIMPULAN}

Sinkronisasi suplai energi dan protein pakan dalam rumen tidak berpengaruh nyata terhadap produksi asam asetat, propionat dan butirat pada 0 jam dan 3 jam setelah pemberian pakan pada rumen domba.

\section{DAFTAR PUSTAKA}

AOAC. 1995. Official Methodes of Analysis. Association of Official Analytical Chemist, Washington, DC.

Hermon, Suharyadi, K. G. Wiryawan and S. Hardjosoewignjo. 2008. Nisbah sinkronisasi pasokan n-protein dan energi dalam rumen sebagai basis formulasi ransum ternak ruminansia. Media Peternakan. 31 (3): 187-193.

Pamungkas, D., Y.N. Anggraeni, Kusmartono dan N.H. Krishna. 2008. Produksi Asam Lemak Terbang Dan Amonia Rumen Sapi Bali Pada Imbangan Daun Lamtoro (L. Leucocephala) Dan Pakan Lengkap Yang Berbeda. Seminar Nasional Teknologi Peternakan dan Veteriner 2008. 200-202.

Piao, M. Y., H. J. Kim., J. K. Seo., T. S. Park., J. S. Yon., K. H. Kim dan J. K. Ha. 2012. Effect of synchronization of carbohydrate and protein suply in total mixed ration with Korean rice wine residue on ruminal fermentation, nitrogen metabolism and microbial protein synthesis in Holstein steers. Asian-Aust. J. Anim. Sci. 25 (11): 1571-1573.

Rahmadi, D., Sunarso., J. Achmadi., E. Pangestu., A. Muktiani., M. Christiyanto., Surono dan Surahmanto. 2010. Ruminologi Dasar. Fakultas Peternakan. Universitas Diponegoro, Semarang.

Richardson, J. M., R. G. Wilkinson dan L. A. Sinclair. 2003. Synchrony of nutrient supply to the rumen and dietary energy source and their effects on the growth and metabolism of lambs. J. Anim Sci. 81:1338-1341.

Sani, F. F., L. K. Nuswantara and A. Subrata. 2012. Degradabilitas bahan kering, bahan organik dan neutral detergent fiber limbah industri pertanian dan perkebunan secara in sacco. Animal Agriculture Journal.1 (1):: 747.

Seo, J. K., J. Yang., H. J. Kim., S. D. Upadhaya., W. M. Cho. dan J. K. Ha. 2010. Effect of synchronization of carbohydrate and protein supply on ruminal fermentation, nitrogen metabolism and microbial protein synthesis in Holstein steers. Asian-Aust. J. Anim. Sci. 23 (11): 1455-1457.

Sinclair, I. A, A.P.C. Garnsworthy, J. R. Newbold dan Buttery. 1993. Effect of synchronizing the rate of dietary energy and nitrogen release on rumen fermentation and microbial protein synthesis in sheep. J. Agric. Sci. 120: 251-263.

Steel, R. G. D. And J. H. Torrie. 1981. Principles and Procedures of Statistics. McGraw-Hill Company Inc., New York. 
Wati, N. E., L. K. Nuswantara, F. Wahyono, E. Pangestu dan J. Achmadi. 2015. The Effects Of Synchronization Of Carbohydrate And Protein Supply In Sugarcane Bagasse Based Ration On Body Composition Of Sheep. J. Indonesian Trop. Anim. Agric. 40(4):226-227.

Zamillah, I. F., R. Yulianto., E. Rianto., E. Purbowati and A. Purnomoadi. Kadar hematokrit, glukosa, urea darah dan keluaran kreatinin kerbau akibat frekuensi pemberian konsentrat yang berbeda. Seminar Nasional Teknologi Peternakan dan Veteriner: 142. 